\title{
Características epistemológicas de publicações científicas em Contabilidade: evidências de um cenário produtivista
}

\author{
Epistemological characteristics of scientific publications in Accounting: evidence of a \\ productivist scenario
}

Características epistemológicas de publicaciones científicas en Contabilidad: pruebas de um escenario productivista

\section{Flaviano Costa}

Doutor em Controladoria e Contabilidade pela Faculdade de Economia, Administração e

Contabilidade da Universidade de São Paulo

Professor do Mestrado em Ciências Contábeis da Universidade Federal do Paraná

Endereço: Av. Prefeito Lothário Meissner, n॰ 632 - Campus III - Jardim Botânico

CEP: 80.210-070 - Curitiba/PR - Brasil

E-mail: flaviano_costa@hotmail.com

Telefone: +55 (41) 9947-4625

\section{Gilberto de Andrade Martins}

Livre Docente em Administração pela Faculdade de Economia, Administração e Contabilidade da Universidade de São Paulo

Professor do Mestrado e Doutorado em Controladoria e Contabilidade da Faculdade de Economia, Administração e Contabilidade da Universidade de São Paulo

Endereço: Av. Prof. Luciano Gualberto, no 908 - Prédio FEA III - Butantã

CEP: 05.508-900 - São Paulo/SP - Brasil

E-mail: martins@usp.br

Telefone: +55 (11) 3091-5820

Artigo recebido em 13/04/2016. Revisado por pares em 02/06/2016. Reformulado em 16/06/2016. Recomendado para publicação em 24/06/2016 por Sandra Rolim Ensslin (Editora Científica). Publicado em 26/08/2016. 


\title{
Resumo
}

O objetivo desta investigação foi levantar e analisar as características epistemológicas em publicações científicas que sinalizam um cenário de produtivismo acadêmico no campo científico contábil, com base na análise de artigos de um periódico considerado de alta qualidade na classificação do Sistema Qualis da CAPES. Trata-se de um estudo documental, com uma amostra de 43 artigos. Os dados foram analisados com emprego de análise de conteúdo. As análises epistemológicas evidenciaram uma preferência por temáticas envolvendo a Contabilidade para usuários externos e mercado de capitais, privilegiando a utilização de dados secundários, por meio de pesquisas documentais. Constatou-se a presença unânime de estudos positivistas e a utilização de modelos econométricos para explicar a realidade observada sem teoria para embasar esses modelos. Por conseguinte, concluiu-se que o campo científico contábil permanece sem modificações teóricas devido ao produtivismo que motivou a criação de uma espécie de "formato ideal" legitimado, institucionalizado e difícil de modificar.

Palavras-chave: Contabilidade - Ensino e pesquisa. Produção científica. Análise epistemológica.

\begin{abstract}
The purpose of this research was to identify and analyze the epistemological characteristics in scientific publications that signal an academic productivism scenario in accounting scientific field, from the analysis of articles from a journal considered high quality in classification of the Qualis System of CAPES. This is a documentary study, with a sample of 43 articles. Data were analyzed with the use of content analysis. Epistemological analysis showed a preference for issues involving the accounting for external users and capital markets, favoring the use of secondary data, through documentary research. It was noted the unanimous presence of positivist studies and use of econometric models to explain the reality observed no theory to support these models. Therefore, it was concluded that the carrying scientific field remains without theoretical changes due to productivism that led to the creation of a kind of "ideal format" legitimized, institutionalized and difficult to modify.
\end{abstract}

Keywords: Accounting - Education and research. Scientific production. Epistemological analysis.

\section{Resumen}

El propósito de esta investigación fue identificar y analizar las características epistemológicas en las publicaciones científicas que indican un escenario de productivismo académico en el campo científico contable, a partir del análisis de los artículos de una revista considerada de alta calidad en la clasificación del Sistema Qualis de la CAPES. Se trata de un estudio documental, con una muestra de 43 artículos. Los datos se analizaron con el uso de análisis de contenido. El análisis epistemológico mostró una preferencia por los temas relacionados con la contabilidad de los usuarios externos y los mercados de capitales, lo que favorece el uso de datos secundarios, a través de la investigación documental. Se observó la presencia unánime de estudios positivistas y uso de modelos econométricos para explicar la realidad observó sin ninguna teoría para apoyar estos modelos. Por lo tanto, se concluyó que el campo científico contable permanece sin cambios teóricos debido a productivismo que llevaron a la creación de una especie de "forma ideal" de legitimado, institucionalizada y difícil de modificar.

Palabras clave: Contabilidad - Educación e investigación. Producción científica. El análisis epistemológico.

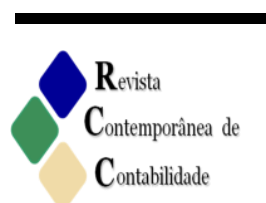

ISSN 2175-8069, UFSC, Florianópolis, v. 13, n. 29, p. 33-68, mai. /ago. 2016 


\section{Introdução}

Muitos estudos e escritos nacionais e internacionais, em diferentes áreas, têm se dedicado à investigação do perfil epistemológico e da qualidade das publicações científicas em seus campos de atuação (SAMUELSON, 1994; CAMÍ, 1997; CHOW; HARRISON, 1998; THEÓPHILO, 2000; CHOW; HARRISON, 2002; LOWE, 2003; BROOME, 2004; THEÓPHILO, 2004; HARZING, 2005; McKNEALLY, 2006; MARTINS, 2007; CASTIEL; SANZ-VALERO, 2007; BAGGS, 2008; MOIZER, 2009; ANDRADE, 2011; ALCADIPANI, 2011; ZAGO, 2011; THOMAZ; MURAMOTO, 2012; YAMAMOTO et al., 2012; WRESZINSKI, 2012; MOSER, 2012; RIGHETTI, 2013; REINACH, 2013; SCHEKMAN, 2013; WOOD Jr., 2014; BIANCHI, 2014; DOMINGUES, 2014; COSTA, 2016; WOOD Jr., 2016) entre outros. A maior parte desses estudos foca o aumento da quantidade de manuscritos e artigos. Em contrapartida, também trata dos problemas qualitativos encontrados em muitas dessas pesquisas; outras, tratam das condutas éticas nos processos investigativos, como as questões de microplágios, autoplágios e gerenciamento de protocolos e resultados (distorções causadas no estudo para se chegar a uma resposta desejada).

Nesse sentido, com relação ao cenário contemporâneo de pesquisas científicas, de acordo com os dados do SCImago Journal \& Country Rank [Editora Elsevier], o Brasil, em 2011, esteve no $13^{\circ}$ lugar no ranking dos países com maior número de artigos publicados [49.664 artigos], num universo de 226 países pesquisados. Contudo, "[...] a qualidade dos trabalhos científicos, medida, por exemplo, pelo número de vezes que cada trabalho foi citado por outros cientistas [...] despencou" (RIGHETTI, 2013). O Brasil passou de $31^{\circ}$ lugar mundial, em 2001, para $40^{\circ}$ lugar em 2011. Em reportagem da Folha de São Paulo, o biólogo Marcelo Hermes-Lima, da Universidade de Brasília, assevera que "[...] a política atual de ensino superior no Brasil pressiona para que os pesquisadores publiquem mais e para que publiquem de qualquer jeito", negligenciando, assim, aspectos qualitativos (RIGHETTI, 2013).

Nesse contexto, Camí (1997) advoga que há uma busca excessiva por publicação e critica o lema "publicar ou perecer". Machado-da-Silva et al. (2008, p. 355) advertem que pode "[...] haver risco de os periódicos irem além do seu papel de disseminador de conhecimento para a valorização superficial de pesquisadores, grupos ou instituições que promovem seu próprio prestígio, muitas vezes mediante publicações espúrias". É importante salientar que essa questão levantada pelos autores não é exclusiva da área contábil ou de qualquer área específica, não ocorrendo apenas no Brasil. Uma evidência disso foi a temática do Encontro Anual da American Accounting Association [AAA], de 2012, que tratava sobre as "sementes da inovação" [seeds of inovation], solicitando mais esforços por parte dos autores no intuito de surpreenderem com ideias e manuscritos inovadores para a evolução da ciência contábil.

Outro indicativo de que essa situação ocorre em outras áreas e em outros países é mostrado no artigo de Tim Albert, em 2002, na New Zealand Journal of Medical Laboratory Science, no qual fornece uma receita de dez passos para publicar cientificamente, sendo o primeiro deles "[...] compreender as regras do jogo para se publicar". De acordo com Castiel e Sanz-Valero (2007, p. 3045), tais passos lembram "[...] os manuais de autoajuda com conselhos para vencer no 'jogo' de escrever artigos científicos. A vitória é tê-los publicados de preferência em revistas importantes". Albert (2002) explicita que o trabalho de publicar pesquisas científicas é uma atividade de venda, na qual se cria um produto (artigo científico) 
para vendê-lo ao cliente (editor). Ao ser aceita a publicação, cumpre-se a transação com sucesso. Diante das evidências expostas por Albert, percebe-se que a priorização por publicação em detrimento da qualidade não é algo específico do Brasil.

Harzing (2005) também apresenta preocupação com o aumento na quantidade e a diminuição na qualidade dos artigos na área de Economics \& Business, na Austrália. Nesses termos, em um artigo escrito para o jornal The Guardian, o biólogo e ganhador do prêmio Nobel de Medicina em 2013, Randy Schekman advoga que o trabalho do cientista deveria ser o de obter grandes avanços em termos sociais, contudo essa função nobre é desconfigurada por meio de incentivos inadequados, tais como reputação pessoal e progressão na carreira, advindas de investigações que impressionam superficialmente, mas não são as melhores em termos sociais. Além disso, Schekman (2013) critica as revistas Nature, Cell e Science, que defendem agressivamente suas marcas com o intuito de vender maior número de assinaturas, e não de estimular pesquisas relevantes. Assim, "[...] como os estilistas que criam bolsas ou roupas de edição limitada, eles sabem que a escassez alimenta a demanda, de modo que propositalmente restringem o número de artigos aceitos para publicação".

Desse modo, é importante uma visão sociológica reflexiva do campo científico contábil. Assim, investigações sobre o conhecimento são sempre muito produtivas, pois, conforme Morin (2010, p. 52), a evolução da ciência é extremamente complexa, uma vez que se configura como um processo em constante movimento e ebulição. $\mathrm{O}$ autor destaca que a ideia de progresso linear de aperfeiçoamento mútuo das teorias deve ser abandonada, uma vez que o conflito de diferentes pontos de vista sobre determinado pensamento científico produz desdobramentos que não podem ser tomados como lineares e ascendentes. Nesse sentido, assevera que "[...] a ciência é um lugar onde se desfraldam os antagonismos de ideias, as competições pessoais e, até mesmo, os conflitos e as invejas mais mesquinhas". Um estudo dessa natureza se mostra necessário no campo da Contabilidade, já que se trata de um campo ainda jovem, mas que vem se consolidando no formato de pós-graduação stricto sensu desde 1970 (ROSELLA et al., 2008). Nesse sentido, acredita-se que o campo da Contabilidade exibe um estágio de publicações e referências tal que necessita lançar um olhar sobre si mesmo.

Em consequência das exposições reunidas até o momento, a presente pesquisa se propõe a responder à seguinte questão: Quais são as características epistemológicas em publicações científicas que sinalizam um cenário de produtivismo acadêmico no campo científico contábil, a partir da análise de artigos de um periódico considerado de alta qualidade na classificação do Sistema Qualis da CAPES? Para a escolha do periódico a ser analisado, foi empregada a classificação no Sistema Qualis da Coordenação de Aperfeiçoamento de Pessoal de Nível Superior [CAPES], que utiliza alguns critérios para mensurar a qualidade das publicações científicas, tais como: normalização, regularidade, periodicidade, origem institucional e geográfica dos autores, gestão editorial, quantidade, proporção e qualidade percebida dos artigos publicados, fator de impacto e indexadores onde os periódicos estão hospedados (CAPES, 2016). Por ser um estudo em profundidade, optou-se por analisar somente dois anos de publicações [2014 e 2015] de apenas um periódico.

Nesses termos, é salutar destacar que as características epistemológicas tratadas no presente estudo não são exaustivas, porquanto foi necessária uma delimitação por questões de viabilidade da pesquisa. Dessa maneira, tais atributos foram classificados de acordo com o modelo proposto por Martins e Theóphilo (2009), adaptado de Bruyne, Herman e Schoutheete (1991). Também é importante ressaltar que os resultados dessa investigação não podem ser 
generalizados porque o recorte espaço-temporal foi limitado a dois anos em um único periódico. Assim sendo, o presente artigo está estruturado em mais quatro seções: [1] referencial teórico para embasar os achados da pesquisa; [2] procedimentos metodológicos utilizados; [3] apresentação e análise dos resultados; e [4] considerações finais e implicações do estudo.

\section{Epistemologia e Contabilidade}

Para Sagan (1997, p. 40), “[...] a ciência é uma tentativa, em grande parte bemsucedida, de compreender o mundo, de controlar as coisas, de ter domínio sobre nós mesmos, de seguir um rumo seguro [...]". Assim sendo, o autor salienta que, para se atingir esse objetivo, o cientista não deve ser fechado a novas ideias, sempre observando que o conhecimento estabelecido é temporário e que nada em ciência é definitivo. Nessa linha pensamento, Lukka (2010) afirma que as pesquisas em Contabilidade são extremamente superficiais na contemporaneidade, devido à falta de avanços com relação às teorias estabelecidas. Esse autor ainda destaca que a ausência de criticidade sobre os elementos metodológicos de determinada área pode trazer risco de que o cientista consiga visualizar apenas as árvores e não toda a floresta, ou seja, consiga realizar trabalhos com qualidade formal, mas com pouca contribuição para a área, por pensar "dentro da caixa". Diante de tal situação, surge a necessidade de uma vigilância crítica sobre essa produção que está sendo realizada e a forma como o saber é construído, tarefa destinada à Epistemologia.

De modo geral, Japiassu (1977) define a Epistemologia etimologicamente como o discurso (logos) sobre a ciência (episteme), mas destaca que essa definição é muito restrita para o número de angulações possíveis que a epistemologia pode assumir em cada ciência que estuda. Nessa linha, Martins e Theóphilo (2009) asseveram que a epistemologia exerce um papel preponderante de questionar criticamente os fundamentos e princípios científicos que são estabelecidos nas diversas ciências. Ao longo da história da formação do pensamento científico, diversas correntes filosóficas, históricas, psicológicas e sociológicas, com seus respectivos representantes, trataram de forma aprofundada sobre os aspectos conceituais e estruturais da Epistemologia, desde a Antiguidade Clássica. Nesse texto, os autores mais condizentes com o objeto da presente pesquisa são consultados.

Em sua trajetória epistemológica, Bachelard (1996, p. 8) traçou, como objetivo principal, por mostrar o destino do pensamento científico abstrato, porquanto somente a abstração "[...] desobstrui o espírito, que ela o torna mais leve e mais dinâmico [...]". Com base nisso, o autor salienta que a formação do espírito científico é um processo que demanda tempo, requer constantes reformulações e implica uma série de renúncias, atribuindo essa dificuldade a um constante exercício de desprendimento porque é preciso, acima de tudo, renunciar aos "achismos" e se desprender de valores pré-concebidos. O filósofo francês ressalta ainda que existem atributos que conduzem à estagnação e causam inércia - os denominados obstáculos epistemológicos.

Nesse sentido, o autor também pondera que: "o conhecimento do real é luz que sempre projeta algumas sombras. Nunca é imediato e pleno" (BACHELARD, 1996, p. 17). Assim, afirma que o ato de conhecer pode se chocar com um preconceito anteriormente adquirido pelo pesquisador, o que remete à dificuldade de desconstruir verdades já legitimadas e aceitar que o conhecimento é sempre provisório. Nas palavras do autor, é impossível anular, de uma 
só vez, "[...] todos os conhecimentos habituais. Diante do real, aquilo que cremos saber com clareza ofusca o que deveríamos saber. Quando o espírito se apresenta à cultura científica, nunca é jovem. Aliás, é bem velho, porque tem a idade de seus preconceitos" (BACHELARD, 1996, p. 18). Em linhas gerais, a cultura científica deve começar, segundo esse filósofo francês, por uma libertação intelectual e afetiva do pesquisador, ou seja, deve-se "[...] substituir o saber fechado e estático por um conhecimento aberto e dinâmico, [...], oferecer enfim à razão razões para evoluir" (BACHELARD, 1996, p. 24), estimulando assim o desenvolvimento do conhecimento e, sobretudo, possibilitando a identificação de obstáculos epistemológicos.

Outra vertente epistemológica importante foi a do falseacionismo, de Karl Popper (1975). De acordo com o autor, a ciência vai se aproximando da realidade à medida que vai se tornando racional pela utilização de um aparato metodológico científico que legitima os resultados da pesquisa pelo critério da falseabilidade. Para a Epistemologia popperiana, é impossível observar sem interpretar e todas as proposições são teóricas. Popper rejeita sistematicamente o método indutivo e todas as inferências que se possam extrair dele, pois, para ele, não é a verificação que define a cientificidade de uma proposição, mas, antes, os testes que possam refutar tal proposição (critério de falseabilidade). É esse conceito de falseabilidade que demarca a fronteira entre ciência e metafisica. Assim sendo, "[...] Popper não se interessa pelo conhecimento enquanto tal, que seria baseado nas 'coisas em si'. Ele prefere, pelo contrário, ancorá-lo em uma abordagem evolucionista que contempla as características propriamente antropológicas desse conhecimento" (VERHAEGHE et al., 2010, p. 76).

Em 1962, outro cientista, Thomas Kuhn, escreveu sua principal obra, a "Estrutura das Revoluções Científicas", na qual defende que o desenvolvimento científico não é um processo contínuo, sinalizando que existem rupturas e alternância de períodos de "ciência normal" e de "revoluções", representando momento de descrédito do paradigma vigente e de transição a novas propostas científicas (KUHN, 2013). Nesses termos, Assis (1993) pondera que, nos períodos de ciência normal, os cientistas se preocupam na articulação do arcabouço conceitual e na aplicabilidade da disciplina à qual se dedicam. Complementa argumentando que, em contraposição, nos períodos de revolução, acontecem os debates e rivalidades entre teorias, sinalizando a substituição total ou parcial de um paradigma por outro novo, conflitante com o anterior, "[...] o que, numa interpretação mais estrita, significa incomensurabilidade entre paradigmas distintos" (GUARIDO FILHO, 2008, p. 38).

Segundo Collins (2001), a obra de Kuhn foi muito influente em sua época para auxiliar a reforçar o ambiente intelectual em que ideias radicais sobre a ciência poderiam florescer e também pondera que a noção da incomensurabilidade paradigmática e suas rupturas indicaram uma maneira de pensar o conhecimento científico como um produto não só da cultura, como também da natureza. Sem dúvida, nesse contexto, o conceito mais conhecido de Kuhn (2013) é o paradigma que pode ser visualizado como uma comunidade científica homogênea e composta por agentes que compartilham compromissos simbólicos e códigos intersubjetivos na maneira com que exercem a atividade científica (KROPF; LIMA, 1999; GUARIDO FILHO, 2008; KUHN, 2013). Assim, Kuhn (2013) julga que esses momentos de modificações nos paradigmas se tornam revolucionários por alterarem os critérios de legitimidade das teorias vigentes em determinada época.

Com base na obra de Kuhn, surgiram diversos outros filósofos da ciência que debateram essas ideias, entre eles: Paul Feyerabend, Imre Lakatos, Larry Laudan, entre 
outros. Nesse sentido, o conceito de programas de pesquisa, semelhante ao paradigma, foi cunhado por Lakatos, que basicamente defende que existem grupos de teorias ligadas, umas às outras, por princípios e postulados comuns. Assim sendo, nesse grupo de teorias "[...] existe um núcleo duro, o núcleo de postulados fundamentais que incentivam a pesquisa, e existe o que ele chama de cinto de segurança que é o dispositivo experimental, observacional que pode se modificar" (MORIN, 2010, p. 46). Diante disso, Feyerabend (2007), considerado um filósofo dissidente e anarquista, rejeitou a ideia de metodologia dos programas de pesquisa de Lakatos, advertindo que buscas para confirmar teorias consolidadas geram resultados acríticos que inibem e restringem a evolução científica.

Portanto, pode-se depreender que a Epistemologia tem inúmeras vertentes de análise, mas, prioritariamente, preocupa-se com a vigilância das produções científicas em determinado ramo do conhecimento. Nesse contexto, a ciência contábil no Brasil vem se desenvolvendo nos últimos anos devido ao aumento dos cursos de pós-graduação stricto sensu, em nível de mestrado e doutorado, tendo, como consequência, um incremento nas publicações científicas (THEÓPHILO, 2004). Contudo, tal crescimento quantitativo ainda não se consubstanciou em evolução efetiva da área em decorrência de fatores como o produtivismo acadêmico. Nesses termos, Lukka (2010) adverte que as pesquisas em Contabilidade ainda parecem se sustentar prioritariamente em pressupostos positivistas, entendendo como verdades empíricas apenas aquelas pautadas em probabilidades, verdades matemáticas e modelos econométricos, mesmo se constatando que a utilização hegemônica de tal corrente filosófica científica está ultrapassada. Destarte, os dois próximos subitens tratam a Contabilidade como práticas social e científica.

\subsection{A Contabilidade como prática social}

De acordo com Littleton (1933), a Contabilidade é progressiva e relativa ao mesmo tempo, pois os fenômenos que constituem seu objeto mudam constantemente, em virtude de novos desafios que surgem para resolução de problemas e da sofisticação dos processos de controle para continuidade empresarial nos mercados competitivos. Esse autor assevera que a Contabilidade se desenvolveu em momentos de crise e evoluiu fornecendo respostas às necessidades das entidades ao longo do tempo, ou seja, "[...] a contabilidade veio de causas definidas e move-se para um destino definido", acompanhando as alterações do ambiente econômico e social das nações (LITTLETON, 1933, p. 362).

Contudo, de acordo com Hopwood (1976), embora reconhecida como importante, muitas vezes a Contabilidade tem sido vista como um fenômeno estático e puramente técnico. Nada poderia estar mais longe da verdade. Os objetivos, processos e técnicas de Contabilidade, em seus papeis humano, organizacional e social, bem como a maneira com que essas informações evidenciadas são utilizadas, nunca foi estática. As ferramentas econômicas desenvolvidas por contadores e os métodos utilizados por eles são criações intelectuais humanas que refletem a evolução social, bem como econômica da Contabilidade. Os profissionais contábeis evoluíram e continuam a evoluir perante as mudanças que ocorrem nos ambientes econômicos, sociais, tecnológicos e políticos das entidades (HOPWOOD, 1976). Colaborando para esse entendimento, Lopes e Martins (2005, p. 2) defendem que "[...] parece-nos simplista demais entender a contabilidade como uma fornecedora de informações econômicas para usuários racionais e ponto final". 
Além disso, Hopwood (1977) pondera ainda que a Contabilidade, como é praticada, e seu desenvolvimento histórico sinalizam a natureza evolutiva e contingente dessa ciência, de forma que, em vez de ser considerada estática e puramente tecnocrática, tem se apresentado tecnologicamente ágil e adaptável ao se relacionar e facilitar processos mais amplos de desenvolvimento empresarial e social. Nessa linha argumentativa, Burchell, Clubb e Hopwood (1985) aduzem que a Contabilidade não deve ser considerada apenas uma técnica e reconhecem que questões sociais podem influenciar a ciência contábil, que, por sua vez, mobiliza e modifica comportamentos de usuários de suas informações.

Nesses termos, a prática contábil surgiu do senso comum e evoluiu para a profissão nos moldes contemporâneos. Essa profissionalização ocorreu por meio de um processo histórico que levou ao desenvolvimento de técnicas, conceitos, doutrinas e demais procedimentos orientados à prática da Contabilidade (MOST, 1982). Tal desenvolvimento das práticas de Contabilidade é documentado por meio de pesquisas históricas, baseadas em investigações arqueológicas que evidenciam a época em que surgiram os registros mais rudimentares que deram origem ao estágio atual da ciência contábil. Segundo Hendriksen e Van Breda (2007), os primeiros registros contábeis remontam a aproximadamente 4 mil anos.

Um dos mais importantes marcos da evolução contábil foi o surgimento do método das partidas dobradas. Não se sabe quem criou essa metodologia, mas se sabe que, em 1494, um frei franciscano, chamado Luca Pacioli, sistematizou a utilização dessa técnica em seu livro intitulado Summa de arithmetica, geometrica, proportioni et proportionalitá, que tratava de Matemática e incluía uma seção sobre escrituração das partidas dobradas, denominada Particularis de Computis et Scripturis (MOST, 1982; HENDRIKSEN; VAN BREDA, 2007). Depois dessa obra, muitos autores começaram a escrever outros livros aplicando o método das partidas dobradas em mosteiros, conventos ou comércios e, assim, os conceitos contábeis foram sendo constituídos com base na prática comercial geral, evoluindo de acordo com a própria evolução da sociedade (MOST, 1982; IUDÍCIBUS, 2006; HENDRIKSEN; VAN BREDA, 2007)

A era da estagnação, que compreendeu o período da Idade Média, acabou com o segundo marco importante da evolução da Contabilidade - a Revolução Industrial -, responsável por um aumento do número e da complexidade das empresas (MOST, 1982). Complementando, Hendriksen e Van Breda (2007) também defendem que foi nessa época que a produção em massa a) o custo significativo dos ativos fixos aumentou, tornando o conceito de depreciação mais relevante; b) a informação gerencial, principalmente sobre os custos das atividades, ganhou mais importância; c) a separação entre investidor e administrador passou a ser indispensável devido aos grandes volumes de capitais investidos; e d) as corporações passaram a ter que reportar as informações financeiras para os usuários externos por meio das demonstrações contábeis, visto que acionistas, credores, investidores e o próprio governo passaram a utilizar esses demonstrativos para tomar suas decisões econômicas.

Devido a essas exigências requeridas pelos usuários externos, atualmente a prática contábil é extremamente influenciada pela regulação de padrões de contabilidade. De acordo com Farias (2012, p. 80), a regulação surgiu "[...] da evolução das organizações e das complexas relações econômicas, sociais e governamentais contemporâneas". Most (1982, p. 12) defende que tal processo consiste em estabelecer padrões para a elaboração e divulgação das informações patrimoniais, econômicas e financeiras, por parte das entidades, para os usuários externos, como: acionistas, investidores, credores, governo, bem como para a sociedade em geral, instaurando assim a chamada "[...] politização da contabilidade".

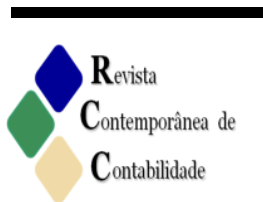

ISSN 2175-8069, UFSC, Florianópolis, v. 13, n. 29, p. 33-68, mai. /ago. 2016 
No cenário contemporâneo, devido à regulação das práticas contábeis, existem organismos regulamentadores da Contabilidade praticamente em todos os países. Contudo, no Brasil, os principais órgãos que influenciam a Contabilidade são o Comitê de Pronunciamentos Contábeis (CPC), o Financial Accounting Standards Board (FASB), americano, e o International Accounting Standards Board (IASB), internacional. Juntamente com esse processo, surge também a literatura da área contábil, quase toda baseada nos processos de regulação da área.

De acordo com Parker, Guthrie e Linacre (2011), a pesquisa contábil é costumeiramente concebida como um estudo aplicado, cujo foco é direcionado para tecnologias e técnicas utilizadas pelos profissionais da Contabilidade em contextos sociais e organizacionais. Desse modo, Tilt (2010) assevera que, para algumas ciências como a Medicina, os resultados das pesquisas são mais fáceis de serem compreendidos pelos usuários, pois resultam em benefícios claros para a sociedade. Entretanto, para a Contabilidade, esse impacto não é tão facilmente perceptível, a ponto de haver alegações de que as investigações na ciência contábil se tornaram demasiadamente distantes dos interesses da profissão e dos profissionais. Portanto, é importante também situar a Contabilidade como prática científica.

\subsection{A Contabilidade como Prática Científica}

A Contabilidade, como atividade científica, ainda é muito incipiente. Em países como os Estados Unidos, as pesquisas acadêmicas, versando sobre temáticas contábeis, vêm se desenvolvendo há pouco mais de meio século, por meio de artigos científicos publicados em periódicos especializados (RYAN; SCAPENS; THEOBALD, 2002). No Brasil, essa prática é ainda mais recente. De acordo com Lopes e Martins (2005), a Contabilidade vem se desenvolvendo academicamente ao longo do século XX, passando a status de ciência e gozando das prerrogativas alusivas a essa realidade.

Segundo Watts e Zimmerman (1986), o cenário atual da pesquisa contábil se desenvolveu com base nos trabalhos de Ball e Brown (1968) e Beaver (1968), que introduziram métodos empíricos conjugados com testagens estatísticas na contabilidade financeira, dando origem à denominada pesquisa positiva. Nesse contexto, tal evento representou grande mudança nas investigações contábeis, em comparação com a primeira metade do século XX, visto que os estudos contábeis realizados até então eram de caráter prioritariamente normativo, cuja preocupação basilar era avaliar "[...] práticas contábeis de acordo com padrões teóricos daquilo que se considerava como ideal. $\mathrm{O}$ 'ideal' normalmente era baseado em conceitos econômicos de lucro e riqueza" (LOPES; MARTINS, 2005, p. 4).

O trabalho de Ball e Brown (1968) analisou os relatórios publicados mensalmente no Wall Street Journal para evidenciar se as informações sobre lucro contábil anormal afetavam os preços das ações no mercado, enquanto a investigação de Beaver (1968), de forma similar, procurou avaliar o comportamento dos preços e volume de títulos negociados nas semanas que precediam a divulgação das informações contábeis por parte das entidades. Desse modo, com base nisso, considerados como pioneiros na mudança de paradigma da pesquisa contábil, foram desenvolvidos muitos estudos envolvendo técnicas estatísticas e econométricas (WATTS; ZIMMERMAN, 1986). A grande maioria dessas investigações segue os modelos de Ball e Brown (1968) e Beaver (1968), buscando encontrar evidências significativas de fatores determinantes no comportamento dos ativos em mercado de capitais. 
De acordo com Farias (2012), uma questão relevante a ser considerada nessa discussão é compreender se essa evolução promovida pela abordagem metodológica positivista também contribuiu para criação e desenvolvimento de teorias próprias para a ciência contábil. Nesse sentido, cabe ressaltar que, apesar do progresso trazido para o campo científico contábil, o enfoque positivista possui limitações, pois reduz tudo a uma equação matemática que simplifica demasiadamente a realidade e esquece, por vezes, o caráter social da Contabilidade (RIPOLL; BARRACHINA, 2000).

No Brasil, o desenvolvimento científico da área contábil iniciou, com mais afinco, a partir da década de 1990. Em seu estudo, Theóphilo (2004) concluiu que, até o final dos anos 1990, as pesquisas científicas contábeis brasileiras eram predominantemente teóricas, normativas e voltadas a propor modelos, novas visões e ideias. Em contraposição, a partir de 2000, com o incremento no número de Programas de Pós-Graduação (PPG) strictu sensu da área de Contabilidade, as investigações passaram a ter uma abordagem empírica, operacionalizadas sob um enfoque metodológico positivista e baseadas em conceitos e teorias existentes, aceitas pela comunidade científica.

Nesses termos, essa transição que ocorreu no final dos anos 1990 foi similar ao ocorrido na década de 1960, nos Estados Unidos, com os trabalhos de Ball e Brown (1968) e Beaver (1968) com praticamente trinta anos de atraso. Destarte, Martins e Theóphilo (2008) ponderam que é indiscutível a evolução científica em Contabilidade, verificada nos últimos anos no Brasil, por meio do aumento do número de PPGs stricto sensu e o consequente incremento de periódicos e eventos científicos na área, facilitando a divulgação de pesquisas. Diante desse aumento gradativo no número de comunicações científicas da área, são importantes os estudos reflexivos e crítico-epistemológicos que examinem o estágio de desenvolvimento dessa produção científica em andamento. Desse modo, a próxima seção trata sobre alguns aspectos do produtivismo acadêmico, que pode estagnar esse crescimento científico da área contábil.

\section{Produtivismo ou Taylorismo Acadêmico: O Mercado do Conhecimento}

Para Reinach (2013), cientistas e instituições, no âmbito contemporâneo, são avaliados por meio de fórmulas matemáticas que combinam três fatores de forma objetiva: [1] número de trabalhos publicados; [2] quantidade de vezes em que esses estudos foram citados na literatura científica da área; e [3] qualidade dos periódicos, mensurados de acordo com a quantidade de citações e trabalhos publicados em revista. $\mathrm{O}$ autor ainda complementa que avaliações subjetivas, tais como qualidade, criatividade e originalidade, não podem ser medidas apenas com dados quantitativos. Em reportagem do jornal O Estado de São Paulo, em 27/04/2013, Reinach pondera que, diante das formas de avaliação de qualidade hoje vigentes, um pesquisador, como Albert Einsten, teria sido excluído do campo científico e afirma que, na atualidade, o teor das conversas entre pós-graduandos e cientistas é a preocupação de saber quantos trabalhos publicou no último ano e onde foram essas comunicações.

No Brasil, foi instituído em 1998, o Sistema Qualis da Coordenação de Aperfeiçoamento de Pessoal de Nível Superior [CAPES], fundação vinculada ao Ministério da Educação, que tem por objetivo avaliar a produção científica dos Programas de PósGraduação stricto sensu. Com base em avaliações realizadas por especialistas, o Sistema 
Qualis utiliza alguns critérios para mensurar a qualidade das publicações científicas, tais como normalização, regularidade, periodicidade, origem institucional e geográfica dos autores, gestão editorial, quantidade, proporção e qualidade percebida dos artigos publicados, fator de impacto e indexadores onde os periódicos estão hospedados (CAPES, 2016).

Contudo, é relevante salientar que esse esforço da CAPES em mensurar qualidade, por meio de critérios algumas vezes questionáveis, que levam as publicações a uma dimensão produtivista, valorizando muito mais a quantidade de comunicações para pontuação e reconhecimento no campo do que para crescimento científico da área, não é o único motivo pelo qual toda esse problema ocorre. Deve-se também ponderar que, imbricados nesse processo científico, encontram-se os editores de periódicos, os avaliadores das publicações científicas e os PPG stricto sensu. Colaborando para esse entendimento, Moizer (2009) afiança que, nas publicações da área de Ciências Sociais, existe uma espécie de jogo no qual existem quatro categorias de participantes: [1] os autores; [2] os revisores; [3] os editores; e [4] os burocratas (órgãos regulamentadores e de fomento).

Diante dessa questão produtivista, Waters (2006) aduz que o mundo acadêmico passa por uma crise generalizada dos sistemas avaliativos criados pelas agências de fomento e regulamentadoras do processo científico, que resulta em uma distorção traduzida em expectativas não razoáveis sobre a quantidade de comunicações que os pesquisadores devem publicar. Nesse contexto, Waters $(2006$, p. 25) ressalta que existem inúmeras publicações excelentes, entretanto elas se perdem em meio a tantos textos ruins. Para o autor, isso é causado pela "[...] insistência na produtividade, sem a menor preocupação com a recepção do trabalho [...] o problema está em fundamentar o acesso ao posto de professor como dependente da quantidade de publicações - publicações que poucos leem [...]".

Castiel e Sanz-Valero (2007) expõem que essa busca por publicação desencadeou um processo irreversível de intensa contabilização numérica de artigos científicos, porém nem sempre com a qualidade necessária para dar manutenção e evolução ao campo de pesquisas a que está associado, ou seja, a qualificação das publicações científicas se tornou, em muitos casos, um aspecto quantitativo e unidimensional. Assim, Castiel e Sanz-Valero (2007) e Wreszinsky (2012) asseveram que esse processo de produção científica pode trazer alguns problemas para os campos de conhecimento, tais como: [1] o "citacionismo", ou estratégia de citações elogiosas, que vem a ser uma corrupção na ideia de fator de impacto; [2] ausência de desvios de teorias estabelecidas, ou seja, as pesquisas quase sempre tratam do mesmo assunto, sem muitas modificações que possam levar à evolução do campo; [3] publicações muito pulverizadas, nas quais uma pesquisa é separada em vários estudos menores para que possa ser divulgada em inúmeros meios de comunicação científica (salami science); [4] aumento do número de autores por artigo (escambo autoral), para todos saírem pontuados; e [5] problemas éticos como plágio, autoplágio e gerenciamento de protocolos.

Nessa mesma linha investigativa, Domingues (2014, p. 226) defende a ideia de taylorismo acadêmico, expressão criada por ele, que se traduz em um mal que atinge, no Brasil e em outras partes do mundo, os cursos de pós-graduação e as pesquisas deles decorrentes "[...] onde as coações e os incentivos à produção de conhecimento novo vão juntos com as formas de auditagem e controle da produção, que são os expedientes administrativos comumente utilizados nas fábricas e nas grandes corporações [...]". Desse modo, para Domingues (2014), os três vetores principais da taylorização acadêmica são: [1] a abertura e a democratização dos processos cognitivos e intelectuais; [2] a dependência da indústria e do capital do emprego de tecnologia intensivas e, portanto, das descobertas e 
aplicações das ciências; e [3] a transformação da ciência e seus produtos em negócio e do cientista em empresário ou em empregado.

Nessa concepção de análise, Domingues (2014) advoga que as principais mazelas da taylorização acadêmica são as métricas utilizadas para medição de qualidade e a formação de rankings que se convertem em artefatos de controle e auditagem, que se estendem às universidades e criam um poder paralelo composto de agentes administrativos que estão apartados e acima dos cientistas e pesquisadores - os chamados burocratas da ciência. Complementando esse raciocínio, o autor pondera que todas essas ocorrências levaram ao lema "publique ou pereça", que causa graves distorções ao sistema de comunicações científicas, como: [1] instalação de uma competição cega, sem uma base cooperativa entre os pesquisadores e instituições; [2] disseminação de fraudes e plágios, nas suas mais variadas formas; e [3] incitação de tempo acelerado para as publicações, o que pode deixar uma obra de talento no vácuo durante muito tempo, por não ser capturada pelos índices de impacto.

Diante desse cenário, Wood Jr. (2016) defende que o produtivismo é uma perversão da produtividade, visto que a última diz respeito ao processo de criação de algum tipo de produto ou serviço a partir do uso consciente e otimizado dos recursos disponíveis, enquanto o primeiro refere-se à produção de algo sem a preocupação com a qualidade e utilidade do que se está produzindo, acumulando-se assim um estoque de mercadorias ou produtos condenados à obsolescência e, por consequência, virar sucata. Ademais, o autor pondera que o produtivismo nas universidades pode ser tratado como uma forma de alienação da missão de gerar conhecimento para desenvolvimento científico, ou seja, é uma corrupção da demanda acadêmica legítima que é a produtividade e relevância social da pesquisa científica.

\section{Procedimentos Metodológicos}

Os procedimentos metodológicos são fundamentais para as pesquisas de caráter científico, visto que, segundo Demo (1995), a atividade da pesquisa é a razão fundante da vida acadêmica e necessita de métodos para ser operacionalizada. Nesses termos, essa seção tem por finalidade descrever o constructo principal da investigação, a amostra utilizada na pesquisa, a técnica de coleta de dados e evidências e o tratamento dado às informações coletadas no estudo.

\subsection{Constructos e Definições Operacionais da Pesquisa}

Levando-se em consideração a manifestação interposta por Martins e Theóphilo (2009) de que uma das principais funções da Epistemologia é a vigilância crítica da pesquisa científica, para essa investigação os constructos denominados "características epistemológicas da produção científica" e "produtivismo" também utilizam esse enfoque dado pelos autores. A ideia é compreender o produto final das pesquisas [publicações científicas] por meio de uma análise aprofundada dos atributos que estas trazem em seu arcabouço, a fim de encontrar as razões que enaltecem o produtivismo em detrimento da qualidade dessas comunicações.

Para operacionalização desses constructos é utilizado o modelo paradigmático quadripolar preconizado por Bruyne, Herman e Schoutheete (1991), adaptado por Martins e Theóphilo (2009). Nesse contexto, Martins e Theóphilo (2009, p. 4) defendem que [1] o polo epistemológico exerce uma função de vigilância crítica da pesquisa; [2] o polo metodológico 
contempla dimensões relacionadas com os diversos modos de tratar a realidade; [3] o polo teórico orienta a definição das hipóteses e construção dos conceitos; [4] o polo técnico guia os procedimentos de coleta de dados e sua transformação em informações pertinentes à questão de pesquisa; [5] o polo de formatação e edição contempla procedimentos para formatação e edição de um trabalho científico, com base nas normas que as disciplinam; e [6] o polo de avaliação compreende o instrumental para avaliações qualitativas e quantitativas. Contudo, para a presente pesquisa o polo de formatação e edição não é utilizado por não apresentar relação direta com a questão investigada.

Cabe salientar que, para operacionalizar o constructo produtivismo, utilizaram-se bases mais subjetivas de análise, procurando-se regularidades e homogeneidades nas categorias usadas nessa investigação, de maneira que proporcionem evidências de que há uma propensão de os pesquisadores encontrarem um "formato ideal" para publicar seus resultados. Para se chegar a esse juízo, levou-se em consideração as críticas interpostas por Martins (2014, p. 106) de que:

\begin{abstract}
as pesquisas empíricas tratadas estatisticamente são mais simples, rápidas, seguras (o artigo é normalmente publicável qualquer que seja o resultado obtido) depois que se dominou um determinado modelo econométrico. E contam pontos mesmo quando sem utilidade. Replicar então, nem se fala, como é fácil e automático na grande maioria das vezes. E o processo de qualificação desses materiais, com a avaliação se dando em função da relevância do assunto e principalmente do resultado obtido, parece não ter se iniciado para valer ainda. Com isso, vê-se, aparentemente, o porquê de o mundo acadêmico haver-se voltado quase que exclusivamente para o mundo positivista: comodidade, redução de tempo e de custo, garantia maior de sucesso na carreira etc. E tudo isso motivado por um processo de avaliação pessoal e institucional que todos criticam, mas que continua sua trajetória. A interferência do modelo de avaliação dos programas acadêmicos parece estar levando a esse triste ponto.
\end{abstract}

Assim, pode-se observar que, com base nas categorizações feitas por meio dos polos epistemológico, metodológico, teórico, técnico e de avaliações qualitativa e quantitativa, aliadas às considerações de Martins (2014), é possível se chegar a evidências de que há condutas produtivistas sendo realizadas pelos pesquisadores do campo científico contábil.

\title{
4.1.1 Polo Epistemológico
}

Admitindo-se que o polo epistemológico tem por função zelar pela vigilância crítica das pesquisas e que "a instância epistemológica do processo de geração de conhecimento compreende os critérios de cientificidade da pesquisa" (MARTINS; THEÓPHILO, 2009, p. 9), no Quadro 1 são evidenciadas as definições operacionais desse polo para a investigação.

\section{Quadro 1 - Definições Operacionais do Polo Epistemológico}

\begin{tabular}{|c|l|}
\hline Categoria & \multicolumn{1}{c|}{ Definição Operacional } \\
\hline \multirow{5}{*}{ Tema } & Contabilidade Gerencial, Controle Gerencial ou Controladoria. \\
& Contabilidade para Usuários Externos. \\
& Contabilidade Aplicada ao Setor Público. \\
& Contabilidade e Finanças (Mercado de Capitais). \\
& Contabilidade Atuarial. \\
& Auditoria Contábil e Perícia Contábil. \\
& Ensino e Pesquisa em Contabilidade. \\
\hline
\end{tabular}




\begin{tabular}{|c|c|}
\hline Categoria & Definição Operacional \\
\hline $\begin{array}{l}\text { Problema de } \\
\text { Pesquisa }\end{array}$ & $\begin{array}{l}\text { Existe enunciação do problema de pesquisa? } \\
\text { Os elementos relevantes do problema de pesquisa estão explicitados? } \\
\text { Há delimitação do problema de pesquisa? } \\
\text { Existe juízo de valor no problema de pesquisa? } \\
\text { A questão de pesquisa é normativa (como fazer algo)? } \\
\text { A questão de pesquisa pode ser respondida com "sim" ou "não"? } \\
\text { Existe relação entre variáveis no problema de pesquisa? } \\
\text { O título, problema de pesquisa e objetivos estão dialogando entre si? }\end{array}$ \\
\hline Causalidade & $\begin{array}{l}\text { Causalidade Explicativa. Relação Assimétrica (uma das variáveis influencia a outra). } \\
\text { Relação Simétrica (nenhuma das variáveis influencia a outra). } \\
\text { Relação Recíproca (variáveis se influenciam mutuamente). } \\
\text { Causalidade Compreensiva. } \\
\text { Causalidade Explicativa e Causalidade Compreensiva. }\end{array}$ \\
\hline Hipóteses & $\begin{array}{l}\text { A pesquisa contém hipóteses? } \\
\text { A hipótese de pesquisa é condizente com o problema de pesquisa e a plataforma teórica? }\end{array}$ \\
\hline Confiabilidade & Foi usada alguma técnica para medição de confiabilidade do instrumento de coleta de dados? \\
\hline $\begin{array}{c}\text { Validade } \\
\text { Interna } \\
\text { (Conteúdo e } \\
\text { Critério) }\end{array}$ & $\begin{array}{l}\text { Há identificação precisa de relações causais? } \\
\text { Existe adequação do método ao problema? } \\
\text { O Referencial Teórico condiz com o problema de pesquisa? } \\
\text { Existe conexão entre a teoria e os dados empíricos? } \\
\text { Inexistem contradições lógicas? }\end{array}$ \\
\hline $\begin{array}{l}\text { Validade de } \\
\text { Constructo }\end{array}$ & $\begin{array}{l}\text { Existem definições operacionais na pesquisa? } \\
\text { São utilizadas múltiplas fontes de evidências na investigação? } \\
\text { O encadeamento das evidências segue uma estrutura lógica? } \\
\text { Existiu algum tipo de avaliação por parte de outros pesquisadores? } \\
\text { Existe um protocolo seguido na apreensão dos dados da pesquisa? }\end{array}$ \\
\hline
\end{tabular}

Fonte: Elaborado pelos autores, com base em Theóphilo (2004) e Martins e Theóphilo (2009).

Logo, pode-se observar que as definições operacionais atinentes ao polo epistemológico dizem respeito ao assunto, tema e problema de pesquisa, causalidade, confiabilidade e validade das investigações, bem como ao encadeamento lógico dos estudos como um todo, no sentido de lhe certificar qualidade e cientificidade.

\subsubsection{Polo Metodológico}

De acordo com Martins e Theóphilo (2009, p. 39), “diferentes modos de conceber a realidade originam maneiras diversas de abordá-la [...]" e, nesse sentido, o polo metodológico pode ser dividido em três categorias distintas: [1] abordagens empírico-positivistas (empirismo, positivismo, abordagem sistêmica e estruturalismo); [2] fenomenológica; e [3] crítico-dialética. Essas são as categorias também utilizadas nesse artigo e descritas no Quadro 2.

Quadro 2 - Definições Operacionais do Polo Metodológico

\begin{tabular}{|c|l|}
\hline Categoria & \multicolumn{1}{|c|}{ Definição Operacional } \\
\hline Abordagem & $\begin{array}{l}\text { Busca de superação da subjetividade, dos juízos de valor e das influências ideológicas. } \\
\text { Somente é considerado verdadeiro o que é empiricamente verificável. } \\
\text { Metodológica } \\
\text { Empirista } \\
\text { Não há, propriamente, teoria; o conhecimento é consequência da passagem do plano } \\
\text { observacional para crescentes generalizações. } \\
\text { Baseada na indução e na busca do conhecimento apenas da face observável da realidade. }\end{array}$ \\
\hline
\end{tabular}

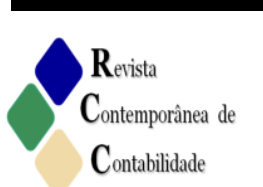

ISSN 2175-8069, UFSC, Florianópolis, v. 13, n. 29, p. 33-68, mai. /ago. 2016 
Características epistemológicas de publicações científicas em Contabilidade:...

\begin{tabular}{|c|c|}
\hline oria & Definição Operacional \\
\hline & $\begin{array}{l}\text { Valorização da capacidade dos sentidos de produzirem evidência e objetividade do dado. } \\
\text { Ênfase na observação empírica, teste experimental e mensuração quantitativa de variáveis. }\end{array}$ \\
\hline $\begin{array}{l}\text { Abordagem } \\
\text { Metodológica } \\
\text { Positivista }\end{array}$ & $\begin{array}{l}\text { Desconfiança na especulação excessiva e rejeição da compreensão subjetiva dos } \\
\text { fenômenos. } \\
\text { Investigação do que é possível conhecer, com renúncia em buscar causas íntimas dos } \\
\text { fenômenos. } \\
\text { Imprescindibilidade de uma teoria para nortear as observações. } \\
\text { Enfase na expressão lógica do discurso científico. } \\
\text { Realidade concebida como formada por partes isoladas, de fatos atômicos. } \\
\text { Ênfase na observação dos fatos. } \\
\text { Busca da explicação dos fenômenos, a partir da identificação das suas relações. } \\
\text { Fenômenos desvinculados de uma dinâmica ampla e estudados por meio de relações } \\
\text { simples, sem aprofundamento nas causas. } \\
\text { Emprego de questionários, entrevistas, escalas de atitudes e de opinião. } \\
\text { Testes de hipóteses e busca de generalizações. }\end{array}$ \\
\hline $\begin{array}{l}\text { Abordagem } \\
\text { Metodológica } \\
\text { Estruturalista }\end{array}$ & $\begin{array}{l}\text { Baseia-se na inteligibilidade profunda do fenômeno e na capacidade da razão humana de } \\
\text { alcançá-la. } \\
\text { O conhecimento da realidade se torna possível quando são identificadas suas formas } \\
\text { subjacentes e invariantes. } \\
\text { A realidade é aparentemente caótica, desordenada. O estudo dos seus elementos internos } \\
\text { profundo, contudo, revela a existência de uma ordem, de uma regularidade. } \\
\text { Conjuntos diferentes podem ser confrontados, não a despeito, mas em virtude de suas } \\
\text { diferenças. } \\
\text { Implica duas ideias: totalidade e interdependência. } \\
\text { Visa descobrir a estrutura do fenômeno, penetrar em sua essência para identificar suas } \\
\text { ligações determinantes. } \\
\text { A estrutura é a sintaxe das transformações que fazem passar de uma variante a outra. Uma } \\
\text { configuração restrita que define um conjunto organizado, ao mesmo tempo, em sua } \\
\text { singularidade e comparabilidade. } \\
\text { Consiste em reconhecer, em conjuntos organizados, diferenças que não sejam puras } \\
\text { alteridades, mas que indiquem a relação comum segundo a qual se definem. } \\
\text { A estrutura visada pela pesquisa se atinge por meio da elaboração de modelos. }\end{array}$ \\
\hline $\begin{array}{l}\text { Abordagem } \\
\text { Metodológica } \\
\text { Sistêmica }\end{array}$ & $\begin{array}{l}\text { Baseia-se na concepção do mundo como uma organização. } \\
\text { Crença na unidade da Ciência, baseada na isomorfia das leis nos diferentes campos do } \\
\text { conhecimento. } \\
\text { Concepções elaboradas nos diversos domínios da Ciência se referem a sistemas. } \\
\text { Privilegia a causalidade em termos de elementos em interação mútua. } \\
\text { Reconhece em uma problemática de pesquisa a predominância do todo sobre as partes. } \\
\text { Privilegia o estudo do objeto de forma globalizada, com ênfase nos seus aspectos estruturais } \\
\text { e nas relações entre seus elementos constitutivos. }\end{array}$ \\
\hline $\begin{array}{c}\text { Abordagem } \\
\text { Metodológica } \\
\text { Fenomenológica }\end{array}$ & $\begin{array}{l}\text { O conhecimento da realidade se dá com a apreensão das características essenciais de todo e } \\
\text { qualquer fenômeno que se manifeste à consciência. } \\
\text { A experiência aplicável ao fenômeno ocorre por meio da vivência. } \\
\text { As essências são apreendidas 'voltando-se as próprias coisas', suspendendo-se a crença na } \\
\text { realidade do mundo exterior. } \\
\text { Fenômeno é tudo aquilo que se mostra ou se revela por si mesmo, todas as formas de estar } \\
\text { consciente de algo. } \\
\text { Essências são as características fundamentais de todo e qualquer fenômeno; aquilo que é } \\
\text { inerente ao fenômeno, sem o qual ele não é mais o fenômeno. } \\
\text { Estudo da experiência vivida diretamente pelo pesquisador ou apreensão da experiência } \\
\text { vivida por outra pessoa. }\end{array}$ \\
\hline Abordagem & realidade é essencialmente contraditória e em permanente transformação. \\
\hline
\end{tabular}




\begin{tabular}{|c|l|}
\hline Categoria & \multicolumn{1}{|c|}{ Definição Operacional } \\
\hline $\begin{array}{c}\text { Metodológica } \\
\text { Dialética }\end{array}$ & $\begin{array}{l}\text { Somente tratando a realidade como processo, e, portanto, sede de contradições entre traços } \\
\text { e finalidades opostas, é que se pode dar sentido lógico à realidade. Somente na perspectiva } \\
\text { da mobilidade, da mudança, é possível compreendê-la. } \\
\text { Visa, simultaneamente, os conjuntos e seus elementos constitutivos. A totalidade e suas } \\
\text { partes; análise e síntese; movimento reflexivo do todo às partes reciprocamente. } \\
\text { É um abalo de todo conhecimento rígido. Todos os elementos do mesmo conjunto se } \\
\text { condicionam reciprocamente em uma infinidade de graus intermediários entre os termos } \\
\text { opostos. } \\
\text { Baseia-se na unidade indissolúvel de duas dimensões: teoria e ação. } \\
\text { Trata da 'coisa em si', mas esta não se apresenta imediatamente ao homem. É preciso fazer } \\
\text { um détour (desvio) para buscar conhecer as coisas e sua estrutura. } \\
\text { O método dialético está vinculado a uma concepção de mundo e romper com o modo de } \\
\text { pensar dominante é condição para se instaurar o método. } \\
\text { É preciso superar as impressões primeiras, as representações fenomênicas dos fatos } \\
\text { empíricos e ascender ao seu âmago, às suas leis fundamentais. } \\
\text { O instrumento metodológico da dialética são as categorias - conceitos básicos que refletem } \\
\text { os aspectos essenciais, propriedades e relações dos fenômenos e objetos. }\end{array}$ \\
\hline
\end{tabular}

Fonte: Elaborado pelos autores, com base em Theóphilo (2004) e Martins e Theóphilo (2009).

Assim sendo, o polo metodológico procurou levantar as bases ontológicas (diferentes maneiras de lançar um olhar para determinado objeto) que foram utilizadas pelos agentes nos artigos selecionados para análise. Ressalta-se que as categorias elencadas no Quadro 2 condizem com a visão dos autores mencionados como fonte para essa tese e podem ter alterações de nomenclatura.

\subsubsection{Polo Teórico}

Martins e Theóphilo (2009) asseveram que as funções mais importantes de uma teoria são explicar e prever os fenômenos da realidade observada. Também destacam que, para se decidir o valor de uma teoria, podem-se levar em consideração alguns critérios: [1] capacidade de descrição, explicação e predição; [2] consistência lógica; [3] perspectivas; [4] fertilidade lógica; e [5] parcimônia. Portanto, as teorias servem de base conceitual para os achados da pesquisa e podem ser confirmadas ou rejeitadas. No Quadro 3, são evidenciadas as definições operacionais desse polo para a investigação.

Quadro 3 - Definições Operacionais do Polo Teórico

\begin{tabular}{|c|l|}
\hline Categoria & \multicolumn{1}{c|}{ Definição Operacional } \\
\hline $\begin{array}{c}\text { Programa de } \\
\text { Desenvolvimento } \\
\text { Científico }\end{array}$ & $\begin{array}{l}\text { Programa de investigação em superfície. } \\
\text { Programa de investigação em profundidade. }\end{array}$ \\
\hline Postura Teórica & $\begin{array}{l}\text { Objetivo cognitivo ou intrínseco. Postura positiva (o que é). } \\
\text { Objetivo utilitário ou extrínseco. Postura normativa (o que deve ser). }\end{array}$ \\
\hline Presença Teórica & $\begin{array}{l}\text { No artigo selecionado existe teoria de base? } \\
\text { O artigo foi embasado somente em conceitos da prática contábil? }\end{array}$ \\
\hline Teoria de Base & Qual teoria foi utilizada para embasar o artigo? \\
\hline
\end{tabular}

Fonte: Elaborado pelos autores, com base em Theóphilo (2004) e Martins e Theóphilo (2009).

Levando-se em consideração que o objetivo da teoria é reconstruir conceitualmente as estruturas objetivas dos fenômenos para delas abstrair a realidade e que "[...] diferentes teorias

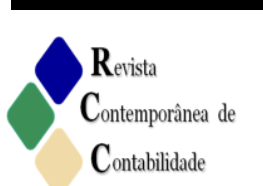

ISSN 2175-8069, UFSC, Florianópolis, v. 13, n. 29, p. 33-68, mai. /ago. 2016 
produzem diferentes instrumentos, diferentes observações e interpretações e, por consequência, diferentes resultados. Constituem diferentes redes para se tentar capturar a realidade" (MARTINS; THEÓPHILO, 2009, p. 28), o polo teórico se preocupa em levantar as estruturas teóricas utilizadas nos artigos selecionados para análise.

\subsubsection{Polo Técnico}

O polo técnico diz respeito às estratégias de pesquisa e às técnicas de coleta de informações, dados e evidências para a consecução de investigações. Nesses termos, Martins e Theóphilo $(2009$, p. 53) ponderam que os aspectos técnicos da pesquisa são realizados com base no conceito de design que corresponde "[...] ao planejamento e estruturação da pesquisa em sua dimensão mais ampla, compreendendo tanto a diagramação quanto a previsão de coleta e análise de informações, dados e evidências". Nessa linha de raciocínio, o Quadro 4 detalha as definições operacionais referentes ao polo técnico para essa investigação.

Quadro 4 - Definições Operacionais do Polo Técnico

\begin{tabular}{|c|c|}
\hline Categoria & Definição Operacional \\
\hline Estratégias de Pesquisa & $\begin{array}{l}\text { Pesquisa Bibliográfica. } \\
\text { Pesquisa Documental. } \\
\text { Pesquisa Experimental. } \\
\text { Pesquisa Quase Experimental. } \\
\text { Levantamento ou Survey. } \\
\text { Estudo de Caso. } \\
\text { Pesquisa-Ação. } \\
\text { Pesquisa Etnográfica. } \\
\text { Construção de Teoria (Grounded Theory). } \\
\text { Outra. }\end{array}$ \\
\hline $\begin{array}{c}\text { Ocorrência do } \\
\text { Fenômeno no Tempo } \\
\end{array}$ & $\begin{array}{l}\text { Acontecimentos históricos. } \\
\text { Acontecimentos contemporâneos. }\end{array}$ \\
\hline $\begin{array}{l}\text { Representação da } \\
\text { Realidade }\end{array}$ & $\begin{array}{l}\text { Situações controladas, pouco próximas dos fenômenos reais. } \\
\text { Situações controladas que se aproximam dos fenômenos reais. } \\
\text { Fenômenos que ocorrem naturalmente no mundo. }\end{array}$ \\
\hline $\begin{array}{l}\text { Controle sobre } \\
\text { Variáveis }\end{array}$ & $\begin{array}{l}\text { Existência de controle sobre as variáveis de estudo. } \\
\text { Inexistência de controle sobre as variáveis de estudo. }\end{array}$ \\
\hline $\begin{array}{l}\text { Técnicas de Coleta e } \\
\text { Análise de Dados }\end{array}$ & $\begin{array}{l}\text { Observação. } \\
\text { Observação Participante. } \\
\text { Pesquisa Documental. } \\
\text { Entrevista. } \\
\text { Focus Group. } \\
\text { Questionário. } \\
\text { Escalas Sociais e de Atitudes. } \\
\text { Análise de Conteúdo. } \\
\text { Análise do Discurso. } \\
\text { História Oral e História de Vida. } \\
\text { Outras. }\end{array}$ \\
\hline Tipos de Dados & $\begin{array}{l}\text { Dados primários. } \\
\text { Dados secundários. }\end{array}$ \\
\hline
\end{tabular}

Fonte: Elaborado pelos autores com base em Theóphilo (2004) e Martins e Theóphilo (2009).

Portanto, pode-se observar que a dimensão técnica da pesquisa privilegia as estratégias e formas de coleta, tratamento e análise de dados coletados para estudo, porquanto se entende 
que, para cada questão de pesquisa que se pretende estudar, há uma metodologia diferenciada a se empregar para respondê-la de forma satisfatória.

\subsubsection{Polo de Avaliação Quantitativa e Qualitativa}

Martins e Theóphilo (2009, p. 107) afiançam que é “[...] descabido o entendimento de que possa haver pesquisa exclusivamente qualitativa ou quantitativa. Investigações científicas contemplam ambas". Nesses termos, os autores complementam que as pesquisas de caráter quantitativo são aquelas em que as evidências podem ser mensuradas, ou seja, os dados são tabulados e organizados de modo que possam ser submetidos a testes estatísticos que orientam a sua análise e interpretação. Contrariamente, as investigações qualitativas pedem descrições, compreensões e interpretações das evidências que naturalmente não são expressas por dados ou números. Contudo, o fato de apresentarem características avaliativas distintas não impede que pesquisas contemplem ambas. Nesse contexto, o Quadro 5 expõe as definições operacionais referentes ao polo de avaliação quantitativa e qualitativa para esse estudo.

Quadro 5 - Definições Operacionais do Polo de Avaliação Quantitativa e Qualitativa

\begin{tabular}{|c|c|}
\hline Categoria & Definição Operacional (MARTINS; THEÓPHILO, 2009) \\
\hline Amostragem & $\begin{array}{l}\text { Amostragem Aleatória Simples. } \\
\text { Amostragem Sistemática. } \\
\text { Amostragem Aleatória Estratificada. } \\
\text { Amostragem por Conglomerados (Clusters). } \\
\text { Métodos de Amostragem Não Probabilísticos. } \\
\text { Existe cálculo de estimação da amostra? }\end{array}$ \\
\hline $\begin{array}{c}\text { Técnicas de Avaliação } \\
\text { Quantitativa }\end{array}$ & $\begin{array}{l}\text { Medidas de Posição ou de Tendência Central e de Dispersão. } \\
\text { Testes de Hipóteses. } \\
\text { Testes Não Paramétricos. } \\
\text { Análise da Variância (ANOVA). } \\
\text { Correlação e Regressão Linear Simples. } \\
\text { Regressão Linear Múltipla. } \\
\text { Análise de Conglomerados. } \\
\text { Análise Fatorial. } \\
\text { Análise de Correspondência. } \\
\text { Análise de Homogeneidade. } \\
\text { Regressão Logística. } \\
\text { Modelagem de Equações Estruturais. } \\
\text { Análise de Dados em Painel. } \\
\end{array}$ \\
\hline $\begin{array}{c}\text { Técnicas de Avaliação } \\
\text { Qualitativa }\end{array}$ & $\begin{array}{l}\text { Observação. } \\
\text { Entrevista. } \\
\text { Análise Documental. } \\
\text { Análise de Conteúdo. } \\
\text { Análise de Discurso. } \\
\text { Outra. }\end{array}$ \\
\hline
\end{tabular}

Fonte: Elaborado pelos autores, com base em Martins e Theóphilo (2009).

Cabe ressaltar que esse polo de avaliações quantitativa e qualitativa da pesquisa foi criado por Martins e Theóphilo (2009), ao expandir as categorias contidas no modelo paradigmático quadripolar, preconizado por Bruyne, Herman e Schoutheete (1991). Nesse contexto, defendem que, apesar de essas duas perspectivas (quantitativa e qualitativa) apresentarem grandes diferenças, não se opõem, mas, pelo contrário, se complementam ao triangularem as análises de uma investigação. 


\subsection{População e Amostra}

A população da pesquisa é composta pelos periódicos com classificação Qualis da CAPES, da área contábil, no período analisado. Contudo, torna-se inviável o estudo da população toda. Por esse motivo, e pelo fato de a pesquisa privilegiar os dados em profundidade, e não em amplitude, optou-se por separar as amostras da seguinte maneira: análise de 43 artigos da área contábil, sendo todos artigos publicados na Revista Contabilidade \& Finanças, entre 2014 e 2015.

Essa escolha se deu pelo fato de o periódico pertencer ao estrato A2 na classificação do Sistema Qualis da CAPES, por ser editado pela Instituição de Ensino Superior dominante no campo científico contábil (Faculdade de Economia, Administração e Contabilidade da Universidade de São Paulo) e também por apresentar uma linha editorial que abrange boa parte das temáticas existentes nas áreas de Contabilidade Gerencial e Controladoria, Contabilidade para Usuários Externos, Contabilidade e Mercado Financeiro, e Ensino e Pesquisa em Contabilidade. Portanto, presume-se que os artigos publicados na Revista Contabilidade \& Finanças foram escritos seguindo rigorosos critérios de qualidade e contemplando o que há de mais atual na pesquisa contábil brasileira. Assim sendo, a presente pesquisa utilizou a seleção de amostra não probabilística do tipo intencional.

\subsection{Tratamento e Análise dos Dados}

Neste estudo, a análise de conteúdo procurou descrever e interpretar as tendências no conteúdo das comunicações pertencentes à área contábil, por meio dos artigos científicos selecionados. De acordo com Bardin (2009, p. 163), para que o analista saiba mais sobre o discurso que está investigando, pode se apoiar em alguns elementos "[...] constitutivos do mecanismo clássico da comunicação: por um lado, a mensagem (significação e código) e o seu suporte ou canal; por outro, o emissor e o receptor, enquanto polos de inferência propriamente ditos". Nessa investigação, as análises foram feitas focando as mensagens.

Existem duas possibilidades de análise de conteúdo por meio da mensagem: o código e a significação. Segundo Theóphilo (2004) e Bardin (2009), o código é um indicador que revela realidades subjacentes, possui uma natureza formal e não é exigido em todos os estudos, enquanto a significação inclui outros destaques na análise de conteúdo. Os autores utilizam como exemplo o campo literário, no qual uma análise do código se preocupa com a diversidade de palavras utilizadas num texto, o comprimento das frases, entre outras. Já uma análise de significação foca os temas debatidos pelos autores ou a sequência lógica que os assuntos são apresentados. Nessa investigação, a análise das mensagens foi realizada por meio da significação, apesar de considerar também nos artigos aspectos formais.

Para que a análise de conteúdo pudesse ser aplicada, foi necessária a construção de categorias de análise apoiadas no referencial teórico. De acordo com Martins e Theóphilo (2009, p. 99), a categorização "[...] é um processo de tipo estruturalista e envolve duas etapas: o inventário (isolamento das unidades de análise: palavras, temas, frases etc.) e a classificação das unidades comuns, revelando as categorias (colocação em gavetas) [...]". Para esse estudo, as categorias e subcategorias foram descritas no item 3.1, por meio dos constructos e das definições operacionais das variáveis em análise. 


\section{Apresentação e Análise dos Resultados}

Para que a pesquisa pudesse ser operacionalizada, foram utilizadas as dimensões preconizadas por Martins e Theóphilo (2010): [1] dimensão epistemológica, propriamente dita; [2] dimensão metodológica; [3] dimensão teórica; [4] dimensão técnica; e [5] dimensão de avaliação qualitativa e quantitativa. Como a intenção não foi tratar os artigos de forma particularizada, as análises foram realizadas de forma conjunta, por isso, nos trechos que exigiram referências explícitas às comunicações, estas foram denominadas "Artigo 1", "Artigo 2", sucessivamente até o "Artigo 43".

\subsection{Dimensão Epistemológica das Publicações}

Seguindo as categorizações elaboradas para o estudo do polo epistemológico, primeiramente se pode observar que a quase totalidade dos artigos são investigações teóricoempíricas, com exceção de um que se trata de pesquisa bibliográfica revisando artigos internacionais sobre as consequências da adoção das normas internacionais de Contabilidade (IFRS) para as entidades. Tal fato pode ser explicado pelo aumento significativo, nos últimos anos, de estudos relacionados à abordagem metodológica positivista, exigindo assim evidências empíricas sobre a realidade estudada. Nesse cenário, na Tabela 1 são exibidos os temas utilizados nos artigos analisados.

Tabela 1 - Temas dos artigos analisados

\begin{tabular}{l|c|r}
\hline \multicolumn{1}{c|}{ Temas } & Ocorrências & \multicolumn{1}{c}{$\%$} \\
\hline Contabilidade e Finanças (Mercado de Capitais) & 15 & 35 \\
\hline Contabilidade para Usuários Externos & 15 & 35 \\
\hline Contabilidade Gerencial, Controle Gerencial ou Controladoria & 4 & 9 \\
\hline Auditoria Contábil e Perícia Contábil & 3 & 7 \\
\hline Contabilidade Atuarial & 3 & 7 \\
\hline Ensino e Pesquisa em Contabilidade & 2 & 5 \\
\hline Contabilidade Aplicada ao Setor Público & 1 & 2 \\
\hline Total & $\mathbf{4 3}$ & $\mathbf{1 0 0}$ \\
\hline
\end{tabular}

Fonte: Elaborada pelos autores.

Diante da Tabela 1, pode-se observar que $70 \%$ dos artigos se preocuparam com o mercado de capitais e com informações da contabilidade societária, destinadas aos usuários externos à entidade. Nesses termos, os assuntos da maior parte dessas pesquisas teóricoempíricas trataram de fatores determinantes da informação contábil que afetam o comportamento das ações no mercado financeiro ou dos efeitos de normatizações específicas sobre a divulgação de informações econômico-financeiras por parte das entidades. Tais investigações utilizaram dados secundários em suas análises e, em sua quase totalidade, foram replicadas de estudos internacionais e adaptadas às características brasileiras.

Considerando-se que as temáticas de "Auditoria e Perícia Contábil" e de "Contabilidade Atuarial" são angulações específicas dos temas "Contabilidade para Usuários Externos" e "Contabilidade e Finanças", respectivamente, pouco se publicou na área de "Contabilidade Gerencial, Controle Gerencial ou Controladoria" (informações para usuário interno) e "Ensino e Pesquisa em Contabilidade". Isso ocorre porque, normalmente, investigações com esses temas exigem coleta de dados primários por meio de questionários,

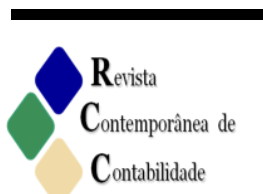

ISSN 2175-8069, UFSC, Florianópolis, v. 13, n. 29, p. 33-68, mai. /ago. 2016 
entrevistas ou técnicas menos usuais na área contábil, tornando o estudo muito mais demorado e trabalhoso, porquanto há uma grande resistência por parte dos agentes em responder esses instrumentos de forma satisfatória.

Mas, além da temática e do assunto desses artigos, também foi importante a análise das questões norteadoras dessas pesquisas, porque "[...] o problema de pesquisa - na maior parte das vezes expresso por meio de questões na forma interrogativa - é um indicador de robustez ou não da proposta de estudo e, sua definição criteriosa, um importante quesito para a consistência lógica do trabalho" (THEÓPHILO, 2004, p. 155). Nesse sentido, averiguou-se que, apesar de ser um dos elementos fundamentais de qualquer estudo científico, oito artigos não enunciaram a pergunta de pesquisa ou o objetivo geral em nenhuma das seções do trabalho, o que pode ser considerado um percentual elevado em uma amostra de 43 artigos, revelando que a qualidade formal dessas investigações não é satisfatória.

Outros pontos também foram levantados nos artigos que continham a questão de pesquisa ou objetivo. Nesse contexto, todas as publicações analisadas explicitaram elementos relevantes e pertinentes ao problema de pesquisa e também delimitaram, de maneira aceitável, os assuntos que foram pesquisados, o que deu a esses trabalhos um caráter de importância pelos resultados obtidos. A quase totalidade dos estudos apresentaram questões estabelecendo relações entre variáveis, o que explica a predominância de artigos do tipo teórico-empírico e a abordagem metodológica positivista. Cabe destacar que nenhuma das questões de pesquisa, consideradas para análise, pôde ser respondida com um simples "sim" ou "não", exigindo um trabalho maior de averiguação.

Ainda com relação às questões de pesquisa, dois artigos apresentaram pontos que envolvem juízo de valor, como se constata no artigo de número 14 isso quando os autores ponderam que "[...] portanto, buscando investigar qual teoria melhor se ajusta à realidade das empresas brasileiras [...]". O mesmo ocorre com o artigo 27: “[...] ao contrário das revisões de literatura já publicadas, consideramos apenas a investigação de fato validada pela revisão por pares de maior prestígio, em vez de concentrarmo-nos em todos os estudos efetuados (publicados ou não)". Desse modo, é muito complexo responder à questão de qual a melhor teoria ou quem tem maior prestígio de forma generalizada, invalidando assim os resultados da investigação, pois não há modo de testar tais problemas de pesquisa empiricamente.

Outro fator relevante a ser salientado é que somente um dos artigos analisados apresentou questão de pesquisa normativa, priorizando o "como fazer" e não o "por que fazer". Esse artigo foi considerado o mais confuso dentre os analisados, pois apresentou três objetivos diferentes e não respondeu satisfatoriamente a nenhum deles. O artigo 5 , em seu problema de pesquisa, apontou isto: “[...] a partir da vigência do Pronunciamento Técnico CPC 15 - Combinação de Negócios, contendo regras compulsórias para divulgação de informações sobre combinação de negócios, quais fatores influenciam o nível de disclosure das operações?". Todavia, se as regras são compulsórias, já se conhecem os fatores que influenciam o nível de divulgação das empresas investigadas, de modo que, se não reportarem as informações, estarão em desalinho com a legislação vigente.

Seguindo a análise da dimensão epistemológica das publicações, foi constatado que a maioria dos artigos (34 no total) apresenta relações assimétricas entre as variáveis, ou seja, em que uma ou mais variáveis influenciam as outras. Em nenhum artigo foi verificada a presença de causalidade compreensiva, porque ela é '[...] 'interna' e refere-se à significação dos fenômenos compreendidos como totalidades por um sujeito [...]" (MARTINS; THEÓPHILO, 2009, p. 12). Desse modo, as abordagens metodológicas convencionais apresentam uma 
causalidade de natureza explicativa, pois se negam a aceitar outra realidade que não seja a dos dados empíricos e das consequências observáveis e as abordagens metodológicas não convencionais se baseiam na causalidade compreensiva. Isso explica a quase totalidade de estudos com relações causais explicativas assimétricas, visto que seguiram uma abordagem metodológica positivista.

$\mathrm{Na}$ sequência de análises, examinou-se a presença de hipóteses nos artigos selecionados para a amostra. De acordo com Kerlinger (1991), hipótese é "[...] um enunciado conjetural das relações entre duas ou mais variáveis. Hipóteses são sentenças declarativas e relacionam de alguma forma variáveis a variáveis. São enunciados de relações, e, como os problemas, devem implicar a testagem das relações enunciadas". Assim, observou-se que, em 21 artigos, houve enunciação de hipóteses e que estas tinham estreita relação com a questão de pesquisa e com os aspectos conceituais e teóricos presentes nas investigações.

Para finalizar as análises da dimensão epistemológica das publicações em Contabilidade, foi verificado se, nos artigos, havia alguma menção à confiabilidade e validade dos instrumentos de medição que as investigações utilizaram. Nesse contexto, Martins e Theóphilo (2009) ponderam que a validade diz respeito à capacidade de o instrumento medir aquilo que se destina medir, e a confiabilidade está associada à constância dos resultados obtidos quando o mesmo indivíduo, ou objeto, é avaliado, medido ou quantificado mais de uma vez. Assim sendo, somente os artigos 7 e 25, utilizaram o Alfa de Cronbach e a Técnica Delphi, respectivamente, para determinar a confiabilidade do instrumento de medição das variáveis que, para esses casos, foi um questionário.

No tocante à validade interna dos instrumentos de pesquisa, observou-se que quase a totalidade dos artigos apresentou as seguintes características: [1] relações causais bem definidas; [2] adequação do método utilizado ao problema de pesquisa proposto; e [3] inexistência de contradições lógicas científicas. Contudo, nos aspectos relacionados à conexão entre a teoria e os dados empíricos e no referencial teórico, houve alguns problemas, visto que a maior parte das investigações analisadas não contemplava uma teoria de base, somente conceitos contábeis de estudos anteriores (replicações de resultados com diferentes pessoas e procedimentos), medidos por meio de equações econométricas complexas e distantes de se tornarem teoria.

Finalmente, quanto à validade de constructo, verificou-se que a maior parte dos artigos definiu operacionalmente as variáveis estudadas, geralmente de forma quantitativa por meio de equações e modelos multivariados. Somente os artigos 1 e 37 utilizaram múltiplas fontes de dados para efetuar uma triangulação, e poucos foram os trabalhos que tiveram o instrumento de medição das variáveis examinado por outros pesquisadores ou fizeram protocolo detalhado do estudo realizado. A ausência desses cuidados não chega a invalidar as pesquisas, porém coloca em dúvida se o instrumento realmente mede a variável estudada na investigação em questão, comprometendo parte dos resultados obtidos.

Por conseguinte, pôde-se apreender, por meio da análise da dimensão epistemológica das publicações científicas selecionadas, que a qualidade formal das comunicações é satisfatória. Contudo, perceberam-se alguns problemas: [1] a maior parte dos artigos são replicações de estudos americanos ou europeus, tropicalizados para uma realidade brasileira; [2] quase a totalidade das publicações é realizada sob a égide da abordagem metodológica positivista; [3] as pesquisas são realizadas buscando-se dados secundários em bases públicas porque o acesso é mais rápido e as informações podem ser mais facilmente manipuladas; [4] os métodos quantitativos e econométricos são exageradamente utilizados para explicar

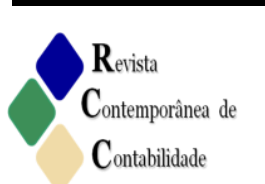

ISSN 2175-8069, UFSC, Florianópolis, v. 13, n. 29, p. 33-68, mai. /ago. 2016 
realidades que não podem ser medidas somente por meio dos números; e [5] há uma falta de teoria para embasar as conclusões dos trabalhos que são realizados somente com foco em conceitos criados por pesquisadores da área contábil. Todo esse estado de coisas favorece, logicamente, o produtivismo acadêmico, facilitando um grande número de publicações em menor tempo.

\subsection{Dimensão Metodológica das Publicações}

Com relação à dimensão metodológica dos artigos selecionados para análise, verificou-se que a totalidade deles apresentou uma abordagem metodológica positivista, corroborando as manifestações de Lukka (2010), que apontou essa evidência nas pesquisas de contabilidade gerencial. Isso é preocupante, visto que foram analisados dois anos do periódico mais bem pontuado pelo Sistema Qualis da CAPES na área de Contabilidade. Nessa linha de raciocínio, Martins (2014, p. 106) advoga que o mundo acadêmico contábil se voltou quase que exclusivamente para a vertente positivista, porque essa perspectiva metodológica traz consigo " [...] comodidade, redução de tempo e de custo, garantia maior de sucesso na carreira etc. E tudo isso motivado por um processo de avaliação pessoal e institucional que todos criticam, mas que continua sua trajetória [...]", ou seja, tudo isso facilita que os agentes possam produzir e publicar muito mais trabalhos em menos tempo, consumindo menos recursos.

Nesse contexto, os artigos selecionados para análise foram classificados na abordagem metodológica positivista por apresentarem certas características predominantes, tais como: busca da explicação dos fenômenos com base na identificação de relações entre variáveis; fenômenos desvinculados de uma dinâmica ampla e estudados por meio de relações simples, sem aprofundamento nas causas, renunciando assim à busca das razões íntimas dos eventos estudados; rejeição do subjetivismo no estudo dos fenômenos; normalmente enunciação de hipóteses e busca de generalizações para o estudo; e ênfase na expressão lógica do discurso científico.

Todavia, deve-se destacar que, na maior parte desses artigos, houve certa dificuldade em classificá-los metodologicamente como positivistas ou empiristas, visto que não contemplam todas as características necessárias para estar em uma única categoria. Apesar de todos os estudos apresentarem as características anteriormente citadas da abordagem positivista, pouquíssimos utilizaram uma teoria para nortear e embasar as observações, empregando somente conceitos da prática contábil, sinalizando assim uma fragilidade teórica. Colaborando para esse entendimento, Demo (2012, p. 21) assevera que o método positivista

[...] mostrou-se efetivo, útil, avassalador, alimentando a pretensão de não só entender, mas, sobretudo, dominar a realidade através da formalização metodológica [...]. A recusa de procedimentos metodológicos mais formalizados implica, muitas vezes, acobertamento de imperícias amadoras de pesquisadores mal apetrechados, tolhidos de uso adequado por insuficiente formação. Saber pesquisar a realidade não é procedimento necessariamente positivista, mas, tomando-se em conta que é mais usual e dominante, cumpre saber lidar com isso, não apenas resistir. Quando menos, isso confere à pesquisa confiabilidade intersubjetiva, "capital acadêmico" crucial para os dias de hoje. De outro lado, é fundamental saber pleitear espaços alternativos, da pesquisa qualitativa, por exemplo, mas com o devido profissionalismo. 
Assim, outro fator relevante que se averiguou, na análise metodológica dos artigos científicos, foi a grande ênfase dada na observação empírica por meio da mensuração quantitativa de variáveis, ou seja, quase a totalidade dos artigos empregou técnicas estatísticas e modelos econométricos para medição das observações investigadas. Destarte, embora se tenha observado traços marcantes da abordagem metodológica positivista, a maioria das investigações gerou conhecimento por meio da passagem do plano observacional para a generalização, sem apoio de uma teoria de base e com grande arsenal econométrico, gerando uma crença na autoexplicação dos testes estatísticos.

\subsection{Dimensão Teórica das Publicações}

No tocante à dimensão teórica das publicações, foram observadas as seguintes categorias: programa de desenvolvimento científico; postura teórica; presença teórica; e teoria de base. Assim sendo, quanto ao programa de desenvolvimento científico, foi verificado se os estudos podiam ser caracterizados como "em superfície", baseando-se em teorias ou conceitos já existentes, ou "em profundidade", levando-se em consideração a proposição de ideias para criação de novas visões e perspectivas teóricas. Diante desse cenário, verificou-se que todos os trabalhos foram qualificados como investigações em superfície.

No que tange à categoria postura teórica, esta pesquisa procurou identificar e classificar os discursos analisados de acordo com o enfoque que apresentam (normativo ou positivo). Segundo Lopes e Martins (2005), nos estudos pautados pelas proposições normativas, busca-se o que é ideal, enquanto nas discussões positivas o foco está na realidade dos agentes econômicos. Iudícibus (2006) expõe que a teoria normativa, apoiada no dedutivismo, procura demonstrar como a Contabilidade "deveria ser", mediante a aplicação de postulados e objetivos axiomáticos, em contraposição à teoria positiva, que é operacionalizada pelo método indutivo e busca descrever a realidade, explicar o porquê dos fenômenos e prever comportamentos da ciência contábil.

Nesse contexto, Theóphilo (2004, p. 150) defende que essas posturas teóricas são fortemente relacionadas e que os pesquisadores da linha normativa devem utilizar "[...] pesquisas positivas para revisão, aperfeiçoamento e validação dos seus modelos [...]", enquanto os agentes, na perspectiva positiva, devem buscar "[...] nas teorias normativas, sustentação para suas hipóteses de pesquisa ou para amparar explicações e achados do seu estudo". Desse modo, nos trabalhos analisados, constatou-se a presença unânime de artigos com postura teórica positiva, ou seja, nenhum artigo fez proposição de modelos ou de "como deve ser" determinado processo, verificando-se uma preferência por estudos que descrevem ou explicam os fenômenos da realidade contábil.

Assim sendo, ao se cruzarem as informações obtidas sobre o programa de desenvolvimento científico com a postura teórica, percebeu-se que a totalidade dos artigos apresentaram trabalhos positivos em superfície, ou seja, investigações que procuram descrever, explicar e prever fenômenos da realidade contábil, amparadas em teorias ou conceitos existentes, em geral amplamente difundidos na área da Contabilidade.

Com relação à presença teórica, constatou-se que apenas seis artigos apresentaram algum tipo de teoria para embasar os resultados; os demais se configuram como estudos replicados que possuem conceitos contábeis consagrados, mas sem teoria que o embasem. Nesses termos, as teorias utilizadas nos estudos analisados foram: Teoria Institucional (Artigo 1); Teoria da Regulação (Artigo 8); Teoria da Agência (Artigos 9 e 40); Teoria da 
Legitimidade, Teoria do Stakeholder e Teoria da Divulgação Voluntária (Artigo 17), e Teoria da Elasticidade (Artigo 19). Contudo, é importante salientar que todas as investigações analisadas fizeram menção a conceitos e estudos anteriores, ou seja , ao menos revisaram a literatura sobre o assunto tratado.

Nesse sentido, é importante que continuem sendo realizadas pesquisas empíricas, quantitativas e positivistas. Contudo, chegou-se ao ponto em que os agentes do campo científico contábil descobriram uma espécie de "fórmula para escrever artigos científicos" e todos saem com as mesmas características, e também com os mesmos problemas lógicos e estruturais, sendo o principal deles a carência teórica, que faz com que a ciência entre em estagnação e permaneça sem atualizações, repetindo indefinidamente as mesmas pesquisas e as mesmas conclusões, por meio de inúmeras replicações.

\subsection{Dimensão Técnica das Publicações}

A dimensão técnica se refere às estratégias de pesquisa e ao instrumental para coleta de dados utilizados nas investigações avaliadas. Nesse sentido, a maior parte dos trabalhos empregou como estratégia a pesquisa documental (34 artigos), seguida de levantamento ou survey (três artigos), pesquisa experimental (dois artigos), pesquisa bibliográfica (dois artigos), estudo de caso (um artigo) e pesquisa quase experimental (um artigo). Essa predominância de pesquisas documentais pode ser explicada pelo fato de utilizarem fontes secundárias de dados, o que facilita o processo de levantamento das evidências e demanda menos tempo para elaboração dos estudos, porque, na maioria das vezes, essas bases de dados são públicas e podem ser acessadas de qualquer local.

Nesse sentido, dos 43 trabalhos examinados, 36 utilizaram fontes de dados secundários em sua elaboração, sendo a maior parte desses dados extraída da Bolsa de Valores de São Paulo (BOVESPA) ou da Comissão de Valores Mobiliários (CVM), entidades do setor público que abrigam, em sua base de dados, os relatórios econômico-financeiros das empresas brasileiras de capital aberto, e da Revista Exame Melhores \& Maiores. Contudo, também se observou a presença de dados retirados de bases pagas pelos programas de pósgraduação em contabilidade, tais como: Economatica, Bloomberg, Bankscope, entre outras. Com relação aos artigos que usaram dados primários em seu escopo, verificou-se que tais evidências foram obtidas por meio de questionários e entrevistas.

Outro fator relevante evidenciado foi que a totalidade dos estudos tiveram como problema de pesquisa acontecimentos contemporâneos, principalmente nas temáticas de contabilidade para usuários externos, com os últimos pronunciamentos contábeis e mudanças de legislações, assim como de contabilidade e finanças, relacionando fatores determinantes para as mutações nas estruturas de mercado, diante dos acontecimentos do cenário atual. Esse fato, combinado com a preferência por pesquisas documentais, comprova a tentativa de diminuição de custo e tempo dos estudos realizados para aumento da produtividade acadêmica.

Confirmando essas ponderações, no que tange às técnicas utilizadas para coleta de dados, averiguou-se que 36 artigos obtiveram dados por meio de documentos, enquanto quatro deles utilizaram questionários, dois combinaram entrevistas e análise documental e um usou análise de conteúdo. Esses achados só vêm a confirmar tudo aquilo já defendido até o presente momento, visto que a análise dos demonstrativos contábeis e demais indicadores corporativos são facilmente encontrados e são de domínio público, sendo que, em grande 
parte das ocasiões e conjugados com métodos estatísticos, formam o mainstream das pesquisas em Contabilidade.

Com relação ao poder que os pesquisadores têm de manipular as variáveis de estudo, somente nos artigos 19, 26 e 32 se percebeu a existência de controle sobre as variáveis investigadas por se tratar de trabalhos experimentais ou quase experimentais. Os demais artigos foram considerados ex post facto, ou seja, constatou-se o relato ou explicação do fenômeno estudado sem interferir ou manipular as evidências coletadas. Esse fato pode ser explicado ao se verificar que a quase totalidade dos trabalhos analisados utilizaram documentos para coleta de dados. Dessa forma, tais fontes, combinadas com o problema de pesquisa a ser respondido, não puderam ser manipuladas para que não fosse gerado viés na investigação. Em consonância com esse achado, também se averiguou que a maior parte dos artigos são marcados por fenômenos que ocorrem naturalmente no mundo, com exceção dos três artigos citados anteriormente (19, 26 e 32), que sinalizam situações controladas, aproximando-se da realidade, por se classificarem como experimentos ou quase experimentos.

Por fim, verificou-se que 25 artigos foram classificados como longitudinais com relação à dimensão temporal e os 18 trabalhos restantes como transversais. Estudos longitudinais são aqueles que abrangem mais de um período de análise, enquanto os transversais fazem um corte temporal em determinada data. Isso explica a grande quantidade de artigos que fazem análises de séries temporais e dados em painel. Nesse sentido, os 25 artigos longitudinais utilizam dados secundários e históricos, normalmente de indicadores e preços de ação de empresas, tentando encontrar relações estatísticas entre essas variáveis.

Desse modo, pôde-se perceber que a dimensão técnica das publicações também apontou fatores que facilitam o produtivismo acadêmico, tais como: [1] preferência por dados secundários pela facilidade de obtenção em bases públicas, ou acessadas por meio dos programas de pós-graduação; [2] falta de inovação nas estratégias de pesquisa, utilizando-se prioritariamente a pesquisa documental, pela facilidade de aquisição dos dados; [3] escolha de estratégias que, combinadas com métodos quantitativos, viabilizam a publicação em tempo e custo menores; e [4] coleta de dados por meio de documentos quase que exclusivamente, não utilizando outras ferramentas de igual importância que captem dados primários (questionários, entrevistas, focus group, escalas sociais e de atitudes).

\subsection{Dimensão de Avaliação Qualitativa e Quantitativa das Publicações}

Quanto à dimensão de avaliação qualitativa e quantitativa das publicações, constatouse que 39 artigos analisados foram classificados como prioritariamente quantitativos, e apenas quatro deles apresentaram características predominantemente qualitativas por meio das técnicas de análise de conteúdo. Nessa perspectiva, observou-se que as avaliações quantitativas foram mais utilizadas por se mostrarem mais compatíveis com a dimensão metodológica positivista. Contudo, é importante destacar as ponderações de Martins e Theóphilo (2009) e Demo (2012) de que é descabido estabelecer uma dicotomia entre pesquisa quantitativa e qualitativa, porquanto as duas se interpenetram e se complementam.

Assim sendo, analisando-se especificamente os 39 trabalhos com perspectiva quantitativa, percebeu-se que todos utilizaram métodos de amostragem não probabilísticos do tipo intencional ou por conveniência, porque os elementos de tais amostras foram escolhidos por critérios de acessibilidade e facilidade na obtenção dos dados, ou de forma proposital por 
parte dos pesquisadores. Nesses termos, em nenhum dos artigos se constatou o cálculo probabilístico de amostras. Tal evidência, combinada com a primazia de estudos documentais, abordagem metodológica positivista, preferência pelas replicações de estudos e falta de presença teórica, permite a realização de estudos superficiais e com pouca capacidade de surpreender e modificar o status quo da ciência contábil.

Outro fator relevante a ser destacado é a crença de que os métodos estatísticos são autoexplicativos e respondem a todos os problemas em pesquisas positivistas. Nessa linha, os artigos prioritariamente quantitativos utilizaram uma ou mais das seguintes técnicas em suas avaliações: estatísticas descritivas (medidas de posição central e de dispersão); testes não paramétricos de Mann-Whitney, Kruskal-Wallis e qui-quadrado; correlação e regressão linear simples; análise de variância (ANOVA); regressão linear múltipla; regressão logística; análise de dados em painel e análise de correspondência. Contudo, essas técnicas, na maioria dos artigos, não foram usadas como elementos intermediários para uma conclusão qualitativa embasada em modelos teóricos, reforçando ou refutando tais teorias. Em oposição a isso, constatou-se o emprego das técnicas estatísticas como resposta final, tentando explicar fenômenos que não podem ser compreendidos somente por meio de equações econométricas.

Nesse contexto, Bourdieu (2013, p. 193) defende que a estatística "[...] que explicita a lógica imanente às condutas de um conjunto de agentes encoraja toda uma série de erros teóricos, alternativos ou simultâneos", se utilizada de forma impensada e manipulada para refletir a realidade por meio de objetivos considerados estratégicos. Complementando essa ideia, Martins (2014, p. 106) assevera que, no campo cientifico contábil, as investigações positivistas, tratadas por meio de técnicas estatísticas, têm aumentado pelo fato de se constituírem em opções mais "simples, rápidas e seguras", visto que são geralmente publicadas, qualquer que seja o resultado obtido, tão somente pelo uso de procedimentos econométricos multivariados de análise. Nesses termos, observou-se que as conclusões dos artigos, normalmente se detinham a descrever os dados estatísticos obtidos por meio das técnicas aplicadas, sem a preocupação com abordagens teóricas ou retomadas conceituais tratadas na revisão da literatura. Exemplos disso são os excertos retirados das conclusões dos artigos 18 e 21 :

Após a realização dos testes e regressões, contatou-se que a opinião do órgão normatizador importa para os investidores, pois encontraram-se evidências de que a divulgação pública da carta emitida pelo IASB ao ESMA impactou o retorno das ações dos bancos que possuíam títulos gregos nos cinco países analisados. (Artigo 18).

Os testes empíricos de associação da proxy de qualidade da auditoria com as variáveis representativas de incentivos à atuação dos auditores confirmaram cinco das sete hipóteses de pesquisa, revelando que a qualidade dos trabalhos tem relação: negativa com o nível de importância do cliente para o auditor; negativa com os trabalhos a partir do sexto ano de contrato; positiva com a instituição do Comitê de Auditoria por parte dos bancos; positiva com o julgamento de processos administradores sancionadores contra os auditores independentes; positiva com o nível de rigor do ambiente regulatório. Das hipóteses testadas, duas não foram confirmadas empiricamente (Artigo 21).

Esses trabalhos são apenas dois exemplos de inúmeras investigações que concluíram fenômenos da realidade contábil apenas com testes estatísticos, mesmo contendo relacionamento de variáveis de caráter subjetivos que exigem, no mínimo, uma triangulação 
qualitativa para se poder concluir algo. No caso dos artigos mencionados, verificou-se que as variáveis "opinião do órgão normatizador" (Artigo 18) e "qualidade da auditoria" (Artigo 21), foram relacionadas com outras variáveis de maneira puramente quantitativa. A intenção não é colocar isso como incorreto ou inaceitável, mas observar que, se houvesse um estudo mais profundo relacionando também aspectos de natureza qualitativa (alcançados por meios de questionários, entrevistas, etc.), os trabalhos ficariam com uma qualidade e confiabilidade muito maior, em consequência da subjetividade de tais constructos, contribuindo assim para uma construção teórica mais robusta, e não visando somente a replicação de estudos.

Pode-se averiguar no Artigo 37 que isso é possível nas pesquisas em Contabilidade. Além de utilizar as demonstrações financeiras e formulários de referência arquivados na CVM, como a maior parte dos artigos analisados, os autores também fizeram entrevistas semiestruturadas com os atores diretamente envolvidos com a variável estudada na investigação "escolhas contábeis". Nesse caso, apesar de existir a modelagem estatística para obtenção da descrição e explicação das relações entre variáveis, tudo faz sentido quando confrontado com a análise qualitativa de conteúdo das entrevistas realizadas, sendo duas visões complementares e não excludentes.

\section{Considerações Finais e Implicações}

O objetivo desta investigação foi levantar e analisar as características epistemológicas em publicações científicas que sinalizam um cenário de produtivismo acadêmico no campo científico contábil com base na análise de artigos de um periódico considerado de alta qualidade na classificação do Sistema Qualis da CAPES. Nesse sentido, epistemologicamente percebeu-se uma preferência por temáticas que envolvem a contabilidade destinada aos usuários externos (legislação, pronunciamentos contábeis e divulgação de informações financeiras) e procedimentos contábeis destinados ao mercado financeiro (fatores determinantes do valor das ações), privilegiando a utilização de dados secundários retirados de bases públicas ou pertencentes aos PPG. Tais evidências, somadas à despreocupação com a confiabilidade e validade dos dados obtidos e a preponderância de estudos replicados de realidades bem diferentes das brasileiras, sem embasamento teórico robusto, assinalam um ambiente produtivista, voltado muito mais para a contabilização numérica de artigos do que para a criação de teorias e crescimento científico da área (LUKKA, 2010; MARTINS, 2014).

De maneira análoga, outras dimensões também apontaram na direção produtivista. Em termos metodológicos, constatou-se a presença unânime de estudos positivistas, com alguns aspectos empiristas (falta de teoria de base e utilização demasiada de métodos quantitativos), mostrando uma ausência de inovação em termos de pesquisas qualitativas e norteadas por abordagens metodológicas alternativas. Teoricamente, o que se averiguou foi muito inquietante, visto que quase a totalidade dos estudos não apresenta teorias, mas somente conceitos retirados dos estudos originais (replicações) ou estudos anteriores referentes à temática, revelando que não existem avanços teóricos nas investigações publicadas.

Com relação à dimensão técnica, verificou-se uma predileção por estudos de natureza documental, com coleta de dados em relatórios econômico-financeiros e demais documentos retirados de bases públicas (CVM, BOVESPA, Banco Central) ou mantidos pelos PPG (Bloomberg, Economatica). Cabe destacar que são em número reduzido os artigos que utilizam estratégias e técnicas de coleta de dados que exigem maior investimento de tempo e

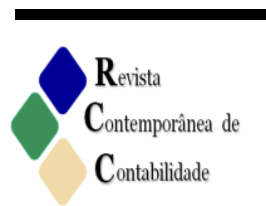

ISSN 2175-8069, UFSC, Florianópolis, v. 13, n. 29, p. 33-68, mai. /ago. 2016 
recursos, porquanto o importante é publicar em revistas bem-avaliadas para pontuar. Finalmente, no tocante às avaliações quantitativa e qualitativa das informações, percebeu-se que a quase totalidade das investigações utilizaram modelos econométricos e estatísticas multivariadas para explicar os fenômenos estudados nas publicações analisadas. Esse fato, aliado à ausência teórica, também é preocupante, visto que é relevante encontrar evidências estatísticas que relacionem variáveis, mas é mais importante explicar o porquê dessa relação.

Assim sendo, algumas possibilidades poderiam ser consideradas em todo esse processo de publicações para que a Contabilidade saia da possível estagnação que está vivenciando. Primeiramente, sob o ponto de vista dos Programas de Pós-Graduação em Contabilidade, é importante que estes façam seu papel de repassar aos alunos as condutas éticas que permeiam o ambiente acadêmico e os valores que os pesquisadores devem observar ao reportarem suas pesquisas, conscientizando cada discente que, mais importante que publicar um número excessivo de artigos, é salutar cuidar do crescimento científico da área com comunicações que realmente façam diferença para a sociedade. Essas dimensões éticas também devem ser observadas pelos editores e avaliadores de periódicos, visto que muitas vezes não são imparciais para aprovar ou rejeitar determinado paper, pelo simples fato de não concordarem com a utilização, mesmo que correta, de determinado método, técnica, estratégia; ou mesmo porque desejam introjetar métodos quantitativos a qualquer custo em publicações com características prioritariamente qualitativas (MARTINS, 2014).

No que tange ao órgão normalizador das pesquisas no Brasil, é perceptível a preocupação, por parte da CAPES, na adoção de medidas que diminuam as condutas publicacionistas. Contudo, ainda há muito por fazer e algumas ações deveriam ser tomadas para que a situação atual possa ser revertida.

É preciso que as grandes áreas científicas possam ser avaliadas em suas especificidades, visto que as Ciências Humanas, Sociais e Exatas, bem como as Artes, não podem ser avaliadas de forma homogeneizada, como ocorre no cenário contemporâneo. Talvez a solução seja, seguindo o mesmo raciocínio de Domingues (2014), que os periódicos passem por avaliações constantes de um comitê formado por diversos experts da área, que avaliem os artigos de forma qualitativa, sem métricas matematizadas, mas observando a contribuição desse estudo para o crescimento científico do campo, fato que exigiria uma maturidade científica muito grande, que possivelmente ainda não se tenha em uma ciência tão nova quanto a Contabilidade, que possui menos de 300 doutores no Brasil.

Entretanto, qualquer pesquisa também possui algumas restrições em suas considerações. Para esse artigo, que é uma pesquisa predominantemente qualitativa e em profundidade, a amostra de artigos (43) não permite análises muito maiores e mais generalizadas sobre o perfil epistemológico das publicações científicas em Contabilidade no Brasil. Por fim, sugere-se que sejam realizadas mais pesquisas sobre essa temática para que se possa avançar no entendimento de outros fatores condicionantes do contexto social das pesquisas em Contabilidade no País e que também seja aumentado o número de artigos e periódicos para maior generalização dos resultados.

\section{Referências}

ALBERT, Tim. Write a scientific paper - the easy way. New Zealand Journal of Medical Laboratory Science, v. 56, n. 1, p. 6-8, 2002. 
ALCADIPANI, Rafael. Resistir ao produtivismo: uma ode à perturbação acadêmica. Caderno EBAPE.BR, v. 9, n. 4, opinião 3, p. 1174-1178, 2011.

ANDRADE, Jesusmar Ximenes. Má conduta na pesquisa em Ciências Contábeis. 2011. 125 f. Tese (Doutorado em Controladoria e Contabilidade) - Curso de Pós-Graduação em Controladoria e Contabilidade, Faculdade de Economia, Administração e Contabilidade da Universidade de São Paulo, São Paulo, 2011.

ASSIS, Jesus de Paula. Kuhn e as ciências sociais. Estudos Avançados, v. 7, n. 19, p. 133164, 1993.

BACHELARD, Gaston. A formação do espírito científico. Rio de Janeiro: Contraponto, 1996.

BAGGS, Judith Gedney. Issues and rules for authors concerning authorship versus acknowledgements, dual publication, self-plagiarism and salami publishing [Editorial]. Research in Nursing \& Health, v. 31, p. 295-297, 2008.

BALL, Ray; BROWN, Philip R. An empirical evaluation of accounting income numbers. Journal of Accounting Research, v. 6, n. 2, p. 159-178, 1968.

BARDIN, Laurence. Análise de Conteúdo. 4. ed. Lisboa: Edições 70, 2009.

BEAVER, William H. The information content of earnings announcements. Empirical research in accounting: selected studies 1968. Journal of Accounting Research, v. 6, p. 67-92, 1968.

BIANCHI, Alvaro. Avaliação acadêmica: muito além do jardim. Blog Convergência. Disponível em: $<$ http://blogconvergencia.org/blogconvergencia/?p=1915>. Acesso em: 19 . mar. 2014. BOURDIEU, Pierre. Homo Academicus. 2. ed. Florianópolis: Editora UFSC, 2013.

BROOME, Marion E. Self-plagiarism: Oxymoron, fair use, or scientific misconduct? [Editorial]. Nursing Outlook, v. 52, n. 6, p. 273-274, 2004.

BRUYNE, Paul de; HERMAN, Jacques; SCHOUTHEETE, Marc de. Dinâmica da pesquisa em ciências sociais: os polos da prática metodológica. 5. ed. Rio de Janeiro: Francisco Alves, 1991.

BURCHELL, Stuart; CLUBB, Colin; HOPWOOD, Anthony G. Accounting in its social context: towards a history of value added in the United Kingdom. Accounting, Organizations and Society, v. 10, n. 4, p. 381-413, 1985.

CAMÍ, Jordi. Impactolatría: diagnóstico y tratamiento. Medicina Clínica, v. 109, n. 13, p. 515-524, 1997. 
CAPES. Coordenação de Aperfeiçoamento de Pessoal de Nível Superior. Disponível em: http://www.capes.gov.br/. Acesso em: 9.6.2016.

CASTIEL, Luis David; SANZ-VALERO, Javier. Entre fetichismo e sobrevivência: o artigo científico é uma mercadoria acadêmica? Caderno de Saúde Pública, v. 23, n. 12, p. 30413050, 2007.

CHOW, Chee W.; HARRISON, Paul D. Factors contributing to success in research and publications: insights of 'influential' accounting authors. Journal of Accounting Education, v. 16, p. 463-472, 1998.

CHOW, Chee W.; HARRISON, Paul D. Identifying meaningful and significant topics for research and publication: a sharing of experiences and insights by 'influential' accounting authors. Journal of Accounting Education, v. 20, p. 183-203, 2002.

COLLINS, Harry M. Sociology of Scientific Knowledge. In: SMELSER, Neil J.; BALTES, Paul B. [organizadores]. International Encyclopedia of the Social \& Behavioral Sciences (pp. 13741-13746). Elsevier, 2001

COSTA, Flaviano. A presença do homo academicus na contabilidade: um olhar bourdieusiano sobre o contexto social do desenvolvimento da produção científica contábil brasileira. 2016. $161 \mathrm{f}$. Tese (Doutorado em Controladoria e Contabilidade) - Curso de PósGraduação em Controladoria e Contabilidade, Faculdade de Economia, Administração e Contabilidade da Universidade de São Paulo, São Paulo, 2016.

DEMO, Pedro. Metodologia Científica em Ciências Sociais. 3. ed. São Paulo: Atlas, 1995.

DEMO, Pedro. Ciência Rebelde: para continuar aprendendo cumpre desestruturar-se. São Paulo: Atlas, 2012.

DOMINGUES, Ivan. O sistema de comunicação da ciência e o taylorismo acadêmico: questionamentos e alternativas. Estudos Avançados, v. 28, n. 81, p. 225-250, 2014.

FARIAS, Manoel Raimundo Santana. Desenvolvimento científico da contabilidade: uma análise baseada na epistemologia realista da ciência. 2012. 222 f. Tese (Doutorado em Controladoria e Contabilidade) - Curso de Pós-Graduação em Controladoria e Contabilidade, Faculdade de Economia, Administração e Contabilidade da Universidade de São Paulo, São Paulo, 2012.

FELIU, Vicente M. R.; PALANCA, Mercedes B. Desenvolvimento científico da contabilidade de gestão. Revista de Administração, 35(1), 98-106, 2000.

FEYERABEND, Paul. Contra o método. São Paulo: Editora UNESP, 2007.

GUARIDO FILHO, Edson Ronaldo. A Construção da Teoria Institucional nos Estudos 
Organizacionais no Brasil: O Período 1993-2007. 2008. 299 f. Tese (Doutorado em Administração) - Curso de Pós-Graduação em Administração, Universidade Federal do Paraná, Curitiba, 2008.

HARZING, Anne-Wil. Australian Research Output in Economics \& Business: high volume, low impact? The Australian Journal of Management, v. 30, n. 2, p. 183-200, 2005.

HENDRIKSEN, Eldon S.; VAN BREDA, Michael F. Teoria da Contabilidade. São Paulo: Atlas, 2007.

HOPWOOD, Anthony G. Editorial. Accounting, Organizations and Society, v. 1, n. 1, p. $1-4,1976$.

HOPWOOD, Anthony G. Editorial. Accounting, Organizations and Society, v. 2, n. 4, p. 277-278, 1977.

IUDÍCIBUS, Sérgio de. Teoria da Contabilidade. 8. ed. São Paulo: Atlas, 2006.

JAPIASSU, Hilton. Introdução ao Pensamento Epistemológico. 2. ed. Rio de Janeiro: Francisco Alves Editora, 1977.

KERLINGER, Fred N. Metodologia da Pesquisa em Ciências Sociais: um tratamento conceitual. São Paulo: EPU/EDUSP, 1991.

KROPF, Simone Petraglia; LIMA, Nísia Trindade. Os valores e a prática institucional da ciência: as concepções de Robert Merton e Thomas Kuhn. História, Ciências, SaúdeManguinhos, v. 5, n. 3, p. 565-581, 1999.

KUHN, Thomas S. Estrutura das revoluções científicas. 12. ed. São Paulo: Perspectiva, 2013.

LITTLETON, Ananias Charles. Accounting Evolution to 1900. New York: American Institute Publishing Company, 1933.

LOPES, Alexsandro Broedel; MARTINS, Eliseu. Teoria da Contabilidade: Uma Nova Abordagem. São Paulo: Atlas, 2005.

LOWE, Nancy K. Publication ethics: copyright and self-plagiarism [Editorial]. Journal of Obstetric, Gynecologic and Neonatal Nursing, v. 32, n. 2, p. 145-146, 2003.

LUKKA, Kari. The roles and effects of paradigms in accounting research. Management Accounting Research, v. 21, p. 110-115, 2010.

MACHADO-DA-SILVA, Clóvis Luiz; GUARIDO FILHO, Edson Ronaldo; ROSSONI, Luciano; GRAEFF, Julia Furlanetto. Periódicos brasileiros de administração: análise bibliométrica de impacto no triênio 2005-2007. RAC-Eletrônica, v. 2, n. 3, p. 351-373, 
2008.

MARTINS, Eliseu. Pensata: Inversão de papéis. Revista Contabilidade \& Finanças, v. 25, n. 65 , p. 105-107, 2014.

MARTINS, Gilberto de Andrade. Avaliação das avaliações de textos científicos sobre contabilidade e controladoria. Revista de Educação e Pesquisa em Contabilidade, v. 1, n. 1, p. 1-13, 2007.

MARTINS, Gilberto de Andrade; THEÓPHILO, Carlos Renato. Produção Científica em Contabilidade no Brasil: Dez "Pecados" mais Frequentes. In: LOPES, Jorge; RIBEIRO FILHO, José Francisco; PEDERNEIRAS, Marcleide. [Organizadores]. Educação

Contábil: Tópicos de Ensino e Pesquisa (p. 1-14). São Paulo: Atlas, 2008.

MARTINS, Gilberto de Andrade; THEÓPHILO, Carlos Renato. Metodologia da

Investigação Científica para Ciências Sociais Aplicadas. 2. ed. São Paulo: Atlas, 2009.

McKNEALLY, Martin. Put my name in that paper: Reflections on the ethics of authorship [Editorial]. The Journal of Thoracic and Cardiovascular Surgery, v. 131, n. 3, p. 517 519, 2006.

MOIZER, Peter. Publishing in accounting journals: A fair game? Accounting, Organizations and Society, v. 34, n. 2, p. 285-304, 2009.

MORIN, Edgard. Ciência com Consciência. 14. ed. Rio de Janeiro: Bertrand do Brasil, 2010 .

MOSER, Donald V. Is Accounting Research Stagnant? Accounting Horizons, v. 26, n. 4, p. 845-850, 2012.

MOST, Kim S. Accounting Theory. 2. ed. Columbus, Ohio: Grid Publishing, Inc, 1982. PARKER, Lee D.; GUTHRIE, James; LINACRE, Simon. Editorial: The relationship between academic accounting research and professional practice. Accounting, Auditing \& Accountability Journal, v. 24, n. 1, p. 5-14, 2011.

POPPER, Karl. A lógica da pesquisa científica. São Paulo: Edusp, 1975.

REINACH, Fernando. Darwin e a prática da 'Salami Science'. O Estado de São Paulo. Disponível em: $<$ http://www.estadao.com.br/noticias/impresso,darwin-e-a-pratica-dasalamiscience, 1026037,0.htm>. Acesso em: 5 fev. 2014.

RIGHETTI, Sabine. Brasil cresce em produção científica, mas índice de qualidade cai. Folha de São Paulo. Disponível em: <http://wwwl.folha.uol.com.br/ciencia/ 2013/04/1266521-brasil-cresce-em-producao-cientifica-mas-indice-de-qualidadecai.shtml>. Acesso em: 5 fev. 2014. 
ROSELLA, Maria Helena; PETRUCCI, Valéria Bezarra C.; PELEIAS, Ivam Ricardo; HOFER, Elza. O ensino superior no Brasil e o ensino da contabilidade. In: PELEIAS, Ivam Ricardo [coordenador]. Didática do ensino da contabilidade - aplicável a outros cursos superiores. São Paulo: Saraiva, 2006.

RYAN, Bob; SCAPENS, Robert W.; THEOBALD, Michael. Research Method \& Methodology in Finance \& Accounting. 2. ed. Singapure: South-Western Cengage Learning, 2002.

SAGAN, Carl. O Mundo Assombrado pelos Demônios: A ciência vista como uma vela no escuro. São Paulo: Companhia das Letras, 1997.

SAMUELSON, Pamela. Self-plagiarism or fair use? Communications of the ACM, v. 37, n. 8, p. 21-25, 1994.

SCHEKMAN, Randy. How journals like Nature, Cell and Science are damaging science. The Guardian. Disponível em: <http://www.theguardian.com/commentisfree/2013 /dec/09/how-journals-nature-science-cell-damage-science>. Acesso em: 10 mar. 2014.

THEÓPHILO, Carlos Renato. Uma Abordagem Epistemológica da Pesquisa em Contabilidade. 2000. 131 f. Dissertação (Mestrado em Controladoria e Contabilidade) Curso de Pós-Graduação em Controladoria e Contabilidade, Faculdade de Economia, Administração e Contabilidade da Universidade de São Paulo, São Paulo, 2000.

THEÓPHILO, Carlos Renato. Pesquisa em Contabilidade no Brasil: Uma Análise Crítico-Epistemológica. 2004. 212 f. Tese (Doutorado em Controladoria e Contabilidade) Curso de Pós-Graduação em Controladoria e Contabilidade, Faculdade de Economia, Administração e Contabilidade da Universidade de São Paulo, São Paulo, 2004.

THOMAZ, Petrônio G.; MURAMOTO, Giovana. Avaliação da qualidade da produção científica brasileira: Devemos criar uma política de cotas? [Carta ao Editor]. Revista do Colégio Brasileiro de Cirurgiões, v. 39, n. 2, p. 168-170, 2012.

TILT, C. A. The impact of academic accounting research on professional practice. In: EVANS, Elaine; BURRITT, Roger; GUTHRIE, James. [Eds]. Accounting education at a crossroad 2010. (pp. 35-40). Institute of Chartered Accountants in Australia, 2010.

VERHAEGHE, Jean-Claude; WOLFS, José Luis; SIMON, Xavier; COMPÈRE, Dominique. Praticar a Epistemologia: um manual de iniciação para professores e formadores. São Paulo: Edições Loyola, 2010.

WATERS, Lindsay. Inimigos da esperança: publicar, perecer e o eclipse da erudição. São Paulo: Editora da UNESP, 2006.

WATTS, Ross; ZIMMERMAN, Jerold. Positive accounting theory. Englewood Cliffs: Prentice Hall, 1986.

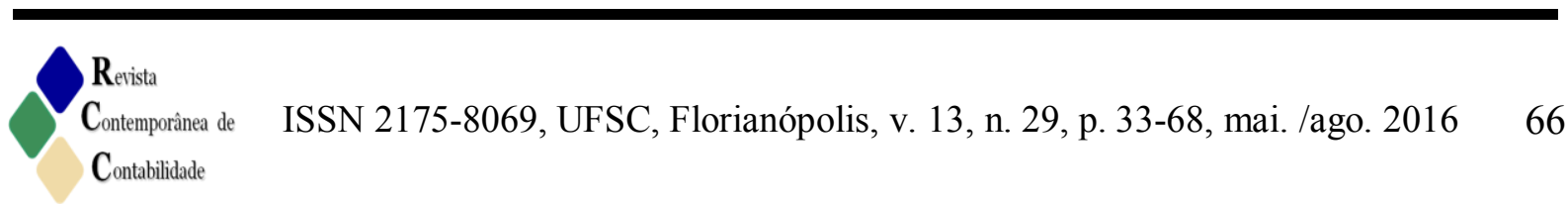


WOOD Jr., Thomaz. A favor da sociedade: As instituições de ensino e pesquisa deveriam orientar mais explicitamente suas ações e políticas, de modo a gerar benefícios tangíveis. Revista Carta Capital. Disponível em: < http://www.cartacapital.com.br/revista/784/afavor-da-sociedade-1229.html>. Acesso em: 5 fev. 2014.

WOOD Jr., Thomaz. Produtivismo e alienação. Revista Carta Capital. Disponível em: < http://www.cartacapital.com.br/revista/901/produtivismo-e-alienacao $>$. Acesso em: 15 jun. 2016.

WRESZINSKY, Walter Felipe. O mito da excelência acadêmica e a curiosidade científica. Jornal da USP, 12-13, outubro de 2012.

YAMAMOTO, Oswaldo H.; TOURINHO, Emmanuel Z.; BASTOS, Antonio Virgílio B.; MENANDRO, Paulo Rogério M. Produção científica e "produtivismo": há alguma luz no final do túnel? RBPG - Revista Brasileira de Pós-Graduação, v. 9, n. 18, p. 727-750, 2012.

ZAGO, Marco Antonio. Perfil da produção científica brasileira. In: Mesa de Discussão Tecnológica. São Paulo: FAPESP. Disponível em: $<\underline{\text { http://www.fapesp.br/eventos }}$ /2011/06/Marco_Antonio.pdf $>$. Acesso em: 5 fev. 2014. 
